University of Nebraska - Lincoln

DigitalCommons@University of Nebraska - Lincoln

Public Health Resources

Public Health Resources

$9-1-2014$

\title{
IFN-gamma AU-rich element removal promotes chronic IFN- gamma expression and autoimmunity in mice
}

\author{
Deborah L. Hodge \\ Laboratory of Experimental Immunology, Cancer and Inflammation Program, Center for Cancer Research, \\ National Cancer Institute-Frederick, MD 21702, USA. Electronic address: hodged@mail.nih.gov., \\ hodged@mail.nih.gov \\ Cyril Berthet \\ Mouse Cancer Genetics Program, Center for Cancer Research, National Cancer Institute-Frederick, \\ Frederick, MD 21702, USA; Oncodesign, 20 Rue Jean Mazen, Dijon 21076, France. Electronic address: \\ cberthet@oncodesign.com., cberthet@oncodesign.com \\ Vincenzo Coppola \\ Mouse Cancer Genetics Program, Center for Cancer Research, National Cancer Institute-Frederick, \\ Frederick, MD 21702, USA; Department of Molecular Virology, Immunology and Medical Genetics at The \\ Ohio State University, 460 W. 12th Street, Columbus, OH 43210, USA. Electronic address: \\ Vincenzo.Coppola@osumc.edu., Vincenzo.Coppola@osumc.edu \\ Wolfgang Kastenmüller \\ Lymphocyte Biology Section, Laboratory of Systems Biology, National Institute of Allergy and Infectious

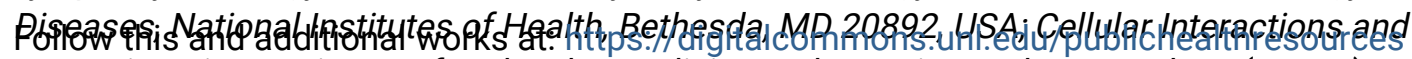 \\ Immunimaging Institutes of Molecular Medicine and Experimental Immunology (IMMEI), University of

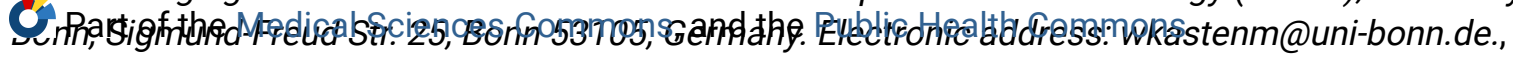 \\ wkastenm@uni-bonn.de
}

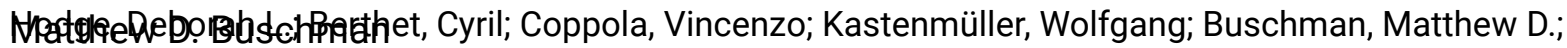

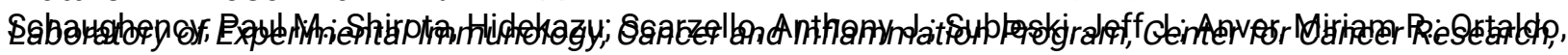

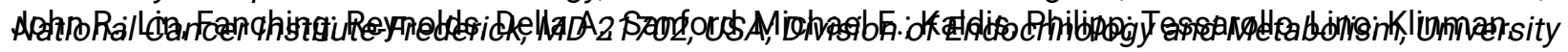

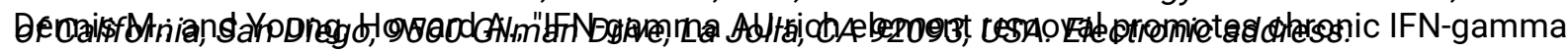

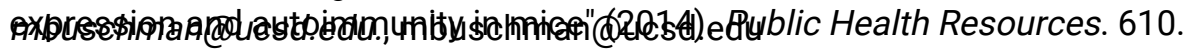

https://digitalcommons.unl.edu/publichealthresources/610

See next page for additional authors

This Article is brought to you for free and open access by the Public Health Resources at

DigitalCommons@University of Nebraska - Lincoln. It has been accepted for inclusion in Public Health Resources

by an authorized administrator of DigitalCommons@University of Nebraska - Lincoln. 


\section{Authors}

Deborah L. Hodge, Cyril Berthet, Vincenzo Coppola, Wolfgang Kastenmüller, Matthew D. Buschman, Paul M. Schaughency, Hidekazu Shirota, Anthony J. Scarzello, Jeff J. Subleski, Miriam R. Anver, John R.

Ortaldo, Fanching Lin, Della A. Reynolds, Michael E. Sanford, Philipp Kaldis, Lino Tessarollo, Dennis M. Klinman, and Howard A. Young 


\title{
IFN-gamma AU-rich element removal promotes chronic IFN-gamma expression and autoimmunity in mice ${ }^{2}$
}

\author{
Deborah L. Hodge $^{\text {a }}$, Cyril Berthet ${ }^{\mathrm{b}, \mathrm{c}}$, Vincenzo Coppola ${ }^{\mathrm{b}, \mathrm{d}}$, Wolfgang Kastenmüller ${ }^{\mathrm{h}, \mathrm{i}}$, \\ Matthew D. Buschman ${ }^{a, e}$, Paul M. Schaughency ${ }^{a, k}$, Hidekazu Shirota ${ }^{a, j}$, \\ Anthony J. Scarzello ${ }^{a}$, Jeff J. Subleski ${ }^{a}$, Miriam R. Anver ${ }^{f}$, John R. Ortaldo ${ }^{a}$, Fanching Lin ${ }^{a}$, \\ Della A. Reynolds ${ }^{a}$, Michael E. Sanford ${ }^{a}$, Philipp Kaldis ${ }^{\text {b,g }}$, Lino Tessarollo ${ }^{\mathrm{b}}$, \\ Dennis M. Klinman ${ }^{a}$, Howard A. Young ${ }^{\mathrm{a}, *}$

\footnotetext{
${ }^{a}$ Laboratory of Experimental Immunology, Cancer and Inflammation Program, Center for Cancer Research, National Cancer Institute-Frederick, MD 21702, USA

${ }^{\mathrm{b}}$ Mouse Cancer Genetics Program, Center for Cancer Research, National Cancer Institute-Frederick, Frederick, MD 21702, USA

' Oncodesign, 20 Rue Jean Mazen, Dijon 21076, France

${ }^{\mathrm{d}}$ Department of Molecular Virology, Immunology and Medical Genetics at The Ohio State University, 460 W. 12th Street, Columbus, OH 43210, USA

${ }^{\mathrm{e}}$ Division of Endocrinology and Metabolism, University of California, San Diego, 9500 Gilman Drive, La Jolla, CA 92093, USA

${ }^{\mathrm{f}}$ Laboratory Animal Science Program (LASP), Science Applications International Corporation (SAIC), National Cancer Institute, Frederick, MD 21702, USA

${ }^{\mathrm{g}}$ Institute of Molecular and Cell Biology (IMCB), A*STAR (Agency for Science, Technology and Research), Proteos, 61 Biopolis Drive, Singapore 138673, Republic of Singapore

${ }^{\mathrm{h}}$ Lymphocyte Biology Section, Laboratory of Systems Biology, National Institute of Allergy and Infectious Diseases, National Institutes of Health, Bethesda, MD 20892, USA

${ }^{\mathrm{i}}$ Cellular Interactions and Immunimaging Institutes of Molecular Medicine and Experimental Immunology (IMMEI), University of Bonn, Sigmund-Freud Str. 25, Bonn 53105, Germany

${ }^{\mathrm{j}}$ Department of Clinical Oncology, Tohoku University Hospital, 1-1 Seiryo-machi, Aoba-ku, Sendai 980-8574, Japan

${ }^{\mathrm{k}}$ Department of Molecular Biology and Genetics, The Johns Hopkins University School of Medicine, Baltimore, MD 21205, USA
}

\section{A R T I C L E I N F O}

\section{Article history:}

Received 31 July 2013

Received in revised form 17 January 2014

Accepted 5 February 2014

Available online 28 February 2014

\section{Keywords:}

Autoimmunity

Systemic lupus erythematosus

Glomerulonephritis

Interferon gamma

\begin{abstract}
A B S T R A C T
We generated a mouse model with a $162 \mathrm{nt}$ AU-rich element (ARE) region deletion in the $3^{\prime}$ untranslated region ( $3^{\prime}$ UTR) of the interferon-gamma (IFN- $\gamma$ ) gene that results in chronic circulating serum IFN- $\gamma$ levels. Mice homozygous for the ARE deletion (ARE-Del) ${ }^{-1-}$ present both serologic and cellular abnormalities typical of patients with systemic lupus erythematosus (SLE). ARE-Del ${ }^{-1}$ mice display increased numbers of pDCs in bone marrow and spleen. Addition of IFN- $\gamma$ to Flt3-ligand (Flt3L) treated in vitro bone marrow cultures results in a 2-fold increase in pDCs with concurrent increases in IRF8 expression. Marginal zone B (MZB) cells and marginal zone macrophages (MZMs) are absent in ARE-Del ${ }^{-1-}$ mice. $\mathrm{ARE}-D e l^{+/-}$mice retain both MZB cells and MZMs and develop no or mild autoimmunity. However, low dose clodronate treatment in ARE-Del ${ }^{+1-}$ mice specifically eliminates MZMs and promotes anti-DNA antibody development and glomerulonephritis. Our findings demonstrate the consequences of a chronic IFN- $\gamma$ milieu on B220 $0^{+}$cell types and in particular the impact of MZB cell loss on MZM function in autoimmunity. Furthermore, similarities between disease states in ARE-Del ${ }^{-1-}$ mice and SLE patients suggest that IFN $-\gamma$ may not only be a product of SLE but may be critical for disease onset and progression.
\end{abstract}

Published by Elsevier Ltd.

\footnotetext{
is The publisher or recipient acknowledges right of the U.S. Government to retain a nonexclusive, royalty-free license in and to any copyright covering the article.

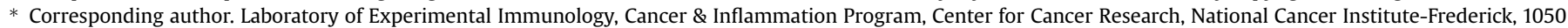
Boyles St, Bldg. 560, Rm. 31-93, Frederick, MD 21702-1201, USA. Tel.: +1 301846 5743; fax: +1 3018461647.

E-mail addresses: hodged@mail.nih.gov (D.L. Hodge), cberthet@oncodesign.com (C. Berthet),Vincenzo.Coppola@osumc.edu (V. Coppola),wkastenm@uni-bonn.de

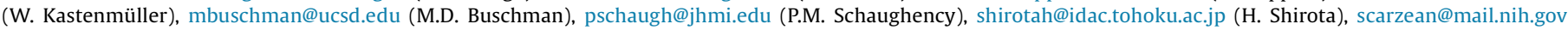

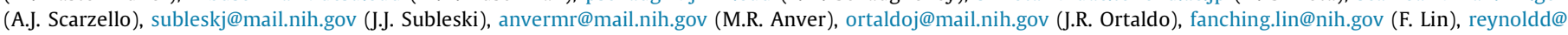

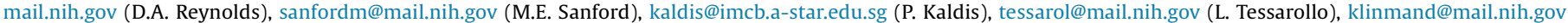
(D.M. Klinman), YoungHow@mail.nih.gov (H.A. Young).
} 


\section{Introduction}

The type II interferon, IFN- $\gamma$, is well-recognized in murine lupus models. IFN- $\gamma$ transgenic mice under the control of the involucrin promoter develop a lupus-like syndrome defined by the autoantibody production, glomerular IgG deposition and glomerulonephritis [1]. Roquin ${ }^{\text {san/san }}$ mice display decreased IFN- $\gamma$ mRNA decay leading to chronic circulating levels of IFN $-\gamma$ and a lupus-like phenotype [2] and offspring from lupus-prone MRL/lpr mice crossed with IFN- $\gamma^{-1-}$ mice have reduced autoantibody titers and less severe end-organ disease [3]. In humans, IFNG gene polymorphisms have been identified in SLE cohorts [4,5] and dysregulated NK cells, T cells, and PBMCs from SLE patients produce elevated amounts of IFN $-\gamma$ that correlate with SLE Disease Activity Index Scores [6-8]. Mechanistically, IFN- $\gamma$ induces B cell activating factor (BAFF), a protein critical for B cell differentiation, proliferation, and survival that has been identified as a therapeutic target in SLE $[4,9]$.

Aberrant IFN- $\gamma$ expression is associated with inflammatory diseases; thus, its expression is tightly controlled. Regulation is complex and involves epigenetic modifications, IFNG promoter interactions with positive and negative regulatory factors (reviewed in [10]) and post-transcriptional control involving nuclear and cytoplasmic mRNA compartmentalization, mRNA stabilization, and miRNAs [11-13] that are partially mediated by IFN- $\gamma 3^{\prime}$ UTR interactions with regulatory proteins human antigen $\mathrm{R}(\mathrm{HuR})$ and tristetraprolin (TTP) [14,15]. Approximately 50\% of the mature IFN$\gamma$ mRNA is $3^{\prime}$ UTR sequence. Little similarity between mouse and human exist with the exception of a 162 nt AU-rich fragment located in the $5^{\prime}$ end of the $3^{\prime} U T R$. AREs are best recognized as mRNA destabilizing elements; thus, we predicted that removal of the IFN- $\gamma$ ARE region would eliminate inhibitory functions resulting in chronic IFN- $\gamma$ mRNA and protein expression. Targeted deletion of an ARE sequence was previously achieved for the tumor necrosis factor-alpha (TNF- $\alpha$ ) gene with subsequent elevated, stable TNF- $\alpha$ expression that coincided with inflammatory arthritis and Crohn's-like inflammatory bowel disease [16].

To examine the consequences of IFN- $\gamma$ ARE deletion on immune function and potential disease development, we generated a mouse with a targeted substitution of the conserved 162 nt AU-rich sequence with random nucleotides. The mice, henceforth called ARE-Del mice, have low, chronic circulating IFN- $\gamma$ levels, a complex phenotype consisting of neutrophilia, monocytosis, anti-nuclear antibodies (ANAs), serum hypocomplementemia, glomerular immunoglobulin and complement deposition, and mesangioproliferative glomerulonephritis; findings consistent with disease similar to human SLE. Importantly, heterozygote mice have normal blood counts, lack elevated autoreactivity, and minimal renal lesions, indicating that a threshold level of IFN- $\gamma$ is critical for development and exacerbation of disease.

\section{Materials and methods}

\subsection{Generation of IFN- $\gamma$ ARE-Del mice}

The IFN- $\gamma$ ARE targeting vector was obtained by recombineering technology [17]. Briefly, we generated two 200 nt PCR fragments from sequences flanking the $5^{\prime}$ and $3^{\prime}$ regions of the IFN- $\gamma 3^{\prime}$ UTR ARE site. PCR products were cloned into PKB644:pLTM260 vector at sites adjacent to a neomycin resistance gene cassette and flanked by loxP and Frt sites. Replacement of the $162 \mathrm{nt}$ ARE-rich sequence was achieved by electroporation of the IFN- $\gamma /$ neomycin cassette into DY380 bacterial strain housing a BAC containing the full-length IFNG gene. A $9.9 \mathrm{~kb}$ sequence containing the recombined locus was retrieved from the BAC, cloned into pBR322, and introduced into a
C57BL/6-129 hybrid embryonic stem cell line and used to generate chimeric mice. The neomycin cassette was removed by crossing chimera offspring with beta-actin Cre-transgenic mice and confirmed by Southern analysis. Subsequent genotyping was performed by PCR with Primer 1 forward, 5'-TTA GGT CAA CAA CCC ACA GGT CCA-3'; Primer 1 reverse, 5'-AGT TGA GGA GAC AGA ACC GCG GTG $-3^{\prime}$; Primer 2 forward, $5^{\prime}$-GCC AAG CAT TCA ATG AGC-3'; Primer 2 reverse, $5^{\prime}$-AAT ACT TCT TTG GTT GAT GC- $3^{\prime}$. PCR product sizes are $284 \mathrm{nt}$ and $224 \mathrm{nt}$ for primer sets 1 and 2, respectively. Two ARE-Del lines, derived from individual ES cell clones, were selected and backcrossed at least 10 generations onto C57BL/6. After backcrossing, mouse genetic backgrounds were assessed at the DartMouse ${ }^{\mathrm{TM}}$ Speed Congenic Core Facility at the Geisel School of Medicine at Dartmouth. DartMouse interrogated 1449 SNPs spread throughout the genome using an Illumina, Inc. (San Diego, CA) GoldenGate Genotyping Assay. The raw SNP data were analyzed using DartMouse's SNaP-Map ${ }^{\mathrm{TM}}$ and Map-Synth ${ }^{\mathrm{TM}}$ software, allowing for genetic background at each SNP location to be determined for individual mice from both ARE-Del breeding lines. Animal care was provided in accordance with the procedures outlined in the "Guide for Care and Use of Laboratory Animals" (National Research Council; 2011; National Academy Press: Washington, D.C.)

\subsection{Cell isolation for flow cytometry analysis}

Bone marrow cells were recovered by flushing the femurs and tibias with RPMI supplemented with $10 \%$ fetal calf serum, $2 \mathrm{mM} \mathrm{L-}$ glutamine, $100 \mathrm{U} / \mathrm{ml}$ penicillin, $100 \mu \mathrm{g} / \mathrm{ml}$ streptomycin, $0.5 \mathrm{mM}$ EDTA (RPMI/EDTA). Leukocytes were isolated from spleen by mechanical disruption of tissue through a filtra-bag mesh (Fisher Scientific) in $10 \mathrm{ml}$ (RPMI/EDTA). Cells counts were determined from the disrupted tissues using a Sysmex KX-21 (Roche) automated cell counter.

\subsection{Flow cytometry analysis}

Cells were stained with antibodies specific for B220, CD19, CD21, CD23, IgM, CD11c, PDCA1, Siglec H, CD86, CD95, GL7, CD4, CD8, F4/ 80, and Ly6G (eBioscience), CD43, CD80, I-A/I-E, IFN- $\gamma$, and IgD (Biolegend). IFN $-\gamma$ Intracellular labeling was done following cell fixation with Cytofix/Cytoperm kit (PharMingen), according to manufacturer's suggested protocol. Data was acquired on a LSRII flow cytometer (BD Biosciences). Data files were analyzed using FCS Express software (De Novo).

\subsection{Spleen marginal zone immunofluorescence staining}

Tissue isolation and slide preparation were performed as previously described [18]. Tissue sections were stained with antibodies specific for CD4 (L3T4; R\&D Systems), CD169 (c3D6.112; AbDSerotec), MARCO (ED31; AbDSerotec), B220 (RA3-6B2; BD), and F4/80 (BM8; Ebioscience).

\subsection{Cytokine, Flt3L, and complement $\mathrm{C} 3$ measurement and antibody titers}

Serum cytokines were analyzed using the mouse cytometric bead array inflammation kit (BD Biosciences) on a FACScan flow cytometer affixed with a 488-nm laser (Becton Dickinson Immunocytometry Systems). IFN- $\alpha$ measurement was performed by ELISA (PBL Interferon Source) at various times following R848 (Invivogen) addition to splenocytes. Complement C3 (Kamiya Biomedical), IFN- $\gamma$ (Biolegend) and Flt3L (Novus Biologicals) detection was performed using ELISA following manufacturer's 
protocol. Mouse serum IgG, IgG1, IgG2b IgG2c, IgG3, IgA, and IgM titers were measured using Ready-Set-Go ELISAs (Ebioscence). All assays were performed according to manufacturer's protocol.

\subsection{Anti-DNA and ANA analysis}

Serum ANA analysis was performed using a fluorescent HEP-2 ANA assay according to manufacturer's protocol (Immunoconcepts). Serum anti-DNA IgG measurements were performed by coating microtiter plates with single and double-stranded DNAs. Serum was added to plates and bound antibody was detected by the addition of alkaline phosphatase (AP)-conjugated goat anti-mouse IgG (Southern Biotechnology) as previously described [19]. AntiDNA Ig reactivity was also measured using mouse anti-dsDNA ELISAs specific for IgG, IgG1, and IgG3 with assays performed according to manufacturer's protocol (Alpha Diagnostic International). For IgG2c-specific anti-dsDNA activity, an anti-dsDNA ELISA assay was modified by substituting an anti-mouse IgG2c-HRP antibody (Alpha Diagnostic International) for the anti-mouse IgGHRP antibody supplied in the kit.

\subsection{Renal immunopathology, blood urea nitrogen, and blood count methods}

One kidney from each mouse was frozen in OCT compound, while the second fixed in $10 \%$ buffered neutral formalin and paraffin-embedded. Both were sectioned at 5 microns. Paraffin embedded sections were stained with periodic acid Schiff (PAS) while frozen sections were stained with pan-immunoglobulin Goat $\mathrm{F}\left(\mathrm{ab}^{\prime}\right) 2$ anti-Mouse $\operatorname{IgM}+\operatorname{IgG}+\operatorname{IgA}(\mathrm{H}+\mathrm{L})$ biotin conjugated (Southern Biotechnology) and anti-complement component C3d (R \& D Systems), biotinylated by the investigator.

Plasma levels of blood urea nitrogen (BUN) assay was performed by NCI-Frederick Pathology/Histotechnology Laboratory (Frederick, $\mathrm{MD})$. CBCs were performed on blood samples collected from the periorbital sinus and analyzed using a Hemavet ${ }^{\circledR}$ analyzer.

\subsection{In vivo clodronate injections}

To measure the effect of clodronate liposomes (CLL) administration on marginal zone macrophages and potential autoimmunity development, groups of $5 \mathrm{WT}$ and 5 heterozygous ARE-Del (ARE$\mathrm{Del}^{+/-}$) mice were injected IV once weekly with $167 \mu \mathrm{g}$ CLL or PBS liposomes (Encapsula Nanosciences) in $200 \mu$ l suspension solution. After 12 weeks, mice were euthanized and blood taken for serum isolation and anti-DNA antibody analysis. Spleen tissue was extracted and examined for loss of marginal zone macrophages by immunoflorescent staining and confocal microscopy as described above. Two animals per treatment group were examined. Kidneys were removed, fixed in $10 \%$ buffered neutral formalin, paraffinembedded, and sectioned at 5 microns. Paraffin embedded sections were stained with periodic acid Schiff (PAS) and examined for kidney lesions. Two animals per treatment group were examined.

\subsection{In vitro $p D C$ culture}

Tibias and femurs of WT and ARE-Del ${ }^{-I-}$ mice were flushed with RPMI-1640 containing 10\% FCS, 2 mM L-glutamine, $100 \mathrm{U} / \mathrm{ml}$ penicillin, $100 \mu \mathrm{g} / \mathrm{ml}$ streptomycin, $50 \mu \mathrm{M} \beta$-mercaptoethanol, and $10 \mathrm{mM}$ HEPES. Cells were washed, ACK treated for $5 \mathrm{~min}$ to lyse RBCs, washed again and plated at a density of $1 \times 10^{6}$ cells $/ \mathrm{ml}$. Flt3L (Peprotech) $+/-$ IFN- $\gamma$ were added at final concentrations of $100 \mathrm{ng} / \mathrm{ml}$ and $10 \mathrm{U} / \mathrm{ml}$, respectively, with additions on days 0 and 6. Cells were maintained in $37{ }^{\circ} \mathrm{C}$ incubator with $5 \% \mathrm{CO}_{2}$ and harvested at days $0,3,6$, and 9 for FACs analysis and RNA isolation.

\subsection{RNA Isolation, RNA half-life determination, and gene expression analysis}

Total RNA was isolated using RNeasy kit (Qiagen) and reverse transcribed into cDNA using superscript III first-strand synthesis system (Invitrogen). Quantitative real time PCR (qRT-PCR) was performed on an Applied Biosystems 7300-real time PCR machine with gene-specific Taqman probes (Invitrogen) for murine IRF-8, E2-2, and HPRT. IFN- $\gamma$ mRNA expression in different tissues was determined using the nCounter Analysis System (NanoString ${ }^{\circledR}$ Technologies) as previously described [20]. RNA half-life studies performed on splenocytes from ARE Del-1- and WT mice with cells placed in culture for $3 \mathrm{~h}$ with PMA/ionomycin stimulation followed with Actinomycin D at $2.5 \mu \mathrm{g} / \mathrm{ml}$. RNAs isolated at various times and qRTPCR performed on cDNAs derived from cellular RNAs to determine IFN- $\gamma$ and actin mRNA levels. IFN- $\gamma$ expression was normalized to actin. Values were plotted to determine IFN- $\gamma$ mRNA half-life.

\subsection{Statistics}

Data sets were analyzed for statistical significance by two-tailed Mann Whitney U or Unpaired Students T test using Graphpad Prism software. $P$-values less than 0.05 were considered significant.

\section{Results}

\subsection{Generation of IFN- $\gamma$ ARE-Del mice}

The 162 nt ARE sequence containing five AUUUA elements and located in the $5^{\prime}$ portion of the IFN- $\gamma 3^{\prime}$ UTR is highly conserved with $83 \%$ identity between human and mouse (Supplemental Fig. 1A). Sequence Replacement was accomplished using recombineering technology (Supplemental Fig. 1B) and confirmed by Southern and PCR analyses (Supplemental Fig. 1C and D). Two lines of ARE-Del mice were generated from different C57BL/6-129 hybrid ES cell clones and were backcrossed more than 10 times on to a C57BL/6 background. Initial characterization of backcrossed mice from both lines revealed auto-reactivity. Because the mice were generated from 129 ES cell hybrids, we were aware that C57BL/6 mice that carry a 129 interval on chromosome 1 display an autoimmune phenotype [21]. The genetic background for each ARE-Del line was determined and found to contain only C57BL/6 sequence on chromosome 1 (Supplemental Fig. 2 A and 2B). Both ARE-Del lines contain a small amount of homozygous 129 sequence on chromosome 3 . This region did not contribute to autoimmunity because both ARE-Del ${ }^{-1-}$ and ARE-Del ${ }^{+/+}$contained the sequence but only ARE-Del $^{-1-}$ mice developed an autoimmune phenotype. The area around the recombined IFNG gene in ARE-Del Line 1 was entirely C57BL/6; however a mixture of C57BL/6 and 129 DNA was identified in this region of ARE-Del Line 2. Again, only ARE-Del ${ }^{-1-}$ mice from both lines developed a disease phenotype demonstrating that 129 DNA in the region did not contribute to autoimmunity. Both ARE-Del lines were similar with regard to all physiological read outs suggesting that changes in the $3^{\prime}$ UTR of the IFNG gene was responsible for disease development. Mice homozygous for the ARE-Del replacement are similar in appearance to WT littermate controls but are not fertile. To obtain ARE-Del ${ }^{-1-}$ mice, ARE-Del ${ }^{+/}$mice are inter-bred, yet, the percentage of ARE-Del ${ }^{-1-}$ mice at weaning is significantly decreased compared to the expected Mendelian ratio, with approximately $11 \%$ of pups homozygous for the deletion.

\subsection{IFN- $\gamma$ mRNA levels are stabilized in IFN- $\gamma$ ARE-deleted mice}

The promoter and protein coding regions of the IFNG gene in ARE-Del mice are unaltered and produce an unmodified full-length 
IFN- $\gamma$ protein. However, deletion of five AUUUA sequences in the $3^{\prime}$ UTR suggested alterations in IFN- $\gamma$ mRNA stability. To test this, splenocytes from ARE-Del ${ }^{-1-}$ mice were stimulated for $3 \mathrm{~h}$ with PMA/ionomycin followed by actinomycin D treatment. Under these conditions, IFN- $\gamma$ mRNA half-life in WT mice was approximately $2 \mathrm{~h}$ with no reduction in IFN- $\gamma$ mRNA levels from ARE-Del ${ }^{-1}$ mice (Fig. 1A) suggesting that ARE deletion significantly stabilizes the IFN- $\gamma$ mRNA.

We next asked if ARE deletion impacted tissue-specific IFN- $\gamma$ mRNA expression and found significant differences in 4 of 6 investigated tissues (Fig. 1B). To determine whether the elevated IFN $-\gamma$ mRNA levels correlated with increased IFN $-\gamma$ protein expression, we performed ELISAs using serum from ARE-Del and WT mice. In WT mice, serum IFN- $\gamma$ levels were below $5 \mathrm{pg} / \mathrm{ml}$ whereas ARE-Del ${ }^{+/-}$and ARE-Del ${ }^{-1-}$ mice displayed an average of $6.3 \mathrm{pg} / \mathrm{ml}$ and $27.6 \mathrm{pg} / \mathrm{ml}$, respectively (Fig. 1C). Intracellular staining demonstrated that under basal conditions, IFN $-\gamma$ was present and significantly elevated in NK, NKT, CD4 ${ }^{+}$and $\mathrm{CD}^{+} \mathrm{T}$ cells from ARE-Del ${ }^{-1-}$ mice (Supplemental Fig. 3A). Moreover, ARE$\mathrm{Del}^{-l-} \mathrm{NK}, \mathrm{CD}^{+}$and $\mathrm{CD}^{+} \mathrm{T}$ cells displayed significant IFN- $\gamma$ increases following in vivo IL-12 treatment. Ex vivo treatment with PMA/ionomycin demonstrated that other cell types such as granulocytes and B cells were capable of producing IFN- $\gamma$ but there was no significant difference between WT and $\mathrm{ARE}^{-\mathrm{Del}^{-1-}}$ mice (Supplemental Fig. 3B). Overall, these results reveal that targeted substitution of the $162 \mathrm{nt}$ AU-rich fragment eliminates important negative regulatory mRNA sequences and elevates IFN- $\gamma$ mRNA and protein levels in a cell specific manner.

\subsection{ARE-Del ${ }^{-/-}$mice present a SLE-like phenotype}

IFN- $\gamma$ involvement in the development lupus-like autoimmunity has been demonstrated by using IFN- $\gamma$ transgenic mice [1], a pristane-induced lupus model [22], and spontaneous lupus models such as NZB X NZW F1 and MRL-Fas ${ }^{\mathrm{lpr}}[23,24]$. In SLE patients, sera IFN- $\gamma$ levels are elevated $[25,26]$ and $T$ cells express significantly higher IFN- $\gamma$ amounts relative to normal donors [4,27]. Initial complete blood count (CBC) analysis from ARE-Del ${ }^{-l-}$ mice revealed monocytosis and neutrophilia (Supplemental Table 1), cellular subsets that increase in both murine-like lupus [28] and human SLE [29].

Autoantibodies, such as anti-nuclear antibodies (ANAs), occur prior to and during SLE progression and correlate with disease activity, particularly in patients with lupus nephritis [30]. Consistent with the lupus-like phenotype, 4 month-old ARE-Del ${ }^{-1-}$ mice displayed strong ANA reactivity (Fig. 2A) and elevated serum antibody titers against single and double-stranded DNAs (Fig. 2B). Interestingly, 2 month-old mice also had significantly higher levels of serum anti-dsDNA antibodies (Supplemental Fig. 4) indicating a correlation between elevated IFN- $\gamma$ and autoreactivity in very young animals.

IFN- $\gamma$ drives IgG class switching from IgG1 to IgG2a/c [31-33]. To determine if elevated IFN- $\gamma$ expression in ARE-Del ${ }^{-1-}$ mice showed an increase in IgG2a/c levels, we assayed serum Igs and found that total IgG levels were similar between ARE-Del ${ }^{-1-}$ and WT control mice (Supplemental Fig. 5). However, ARE-Del ${ }^{-1-}$ mice displayed reduced levels of IgG1 and IgG3 and had elevated IgG2c titers consistent with the role of IFN $-\gamma$ in Ig class switching. We also examined IgA and IgM serum levels and found no difference in IgA levels between groups. In contrast, IgM levels were significantly elevated in the ARE-Del ${ }^{-1-}$ mice. To determine what IgG isotype(s) contributed to the anti-dsDNA reactivity in the ARE-Del mice, we determined serum IgG, IgG1, IgG2c and IgG3 anti-dsDNA titers and found that IgG2c was the major contributor to the DNA autoreactivity (Fig. 2C). In other murine models of lupus, $\operatorname{IgG} 2 \mathrm{a} / \mathrm{c}$ is reported to be a more pathogenic Ig isotype by efficiently activating FcgammaRIII and FcgammaRIV receptors and complement [34]. Thus, it is conceivable that IFN- $\gamma$ aids in lupuslike disease development by its role immunoglobulin class switching.

A serious manifestation of SLE is glomerulonephritis. We performed histological analysis on renal sections from 4 month old WT and ARE-Del ${ }^{-1-}$ mice. Periodic Acid Schiff staining revealed altered glomerular structures, thickened mesangium and an absence of
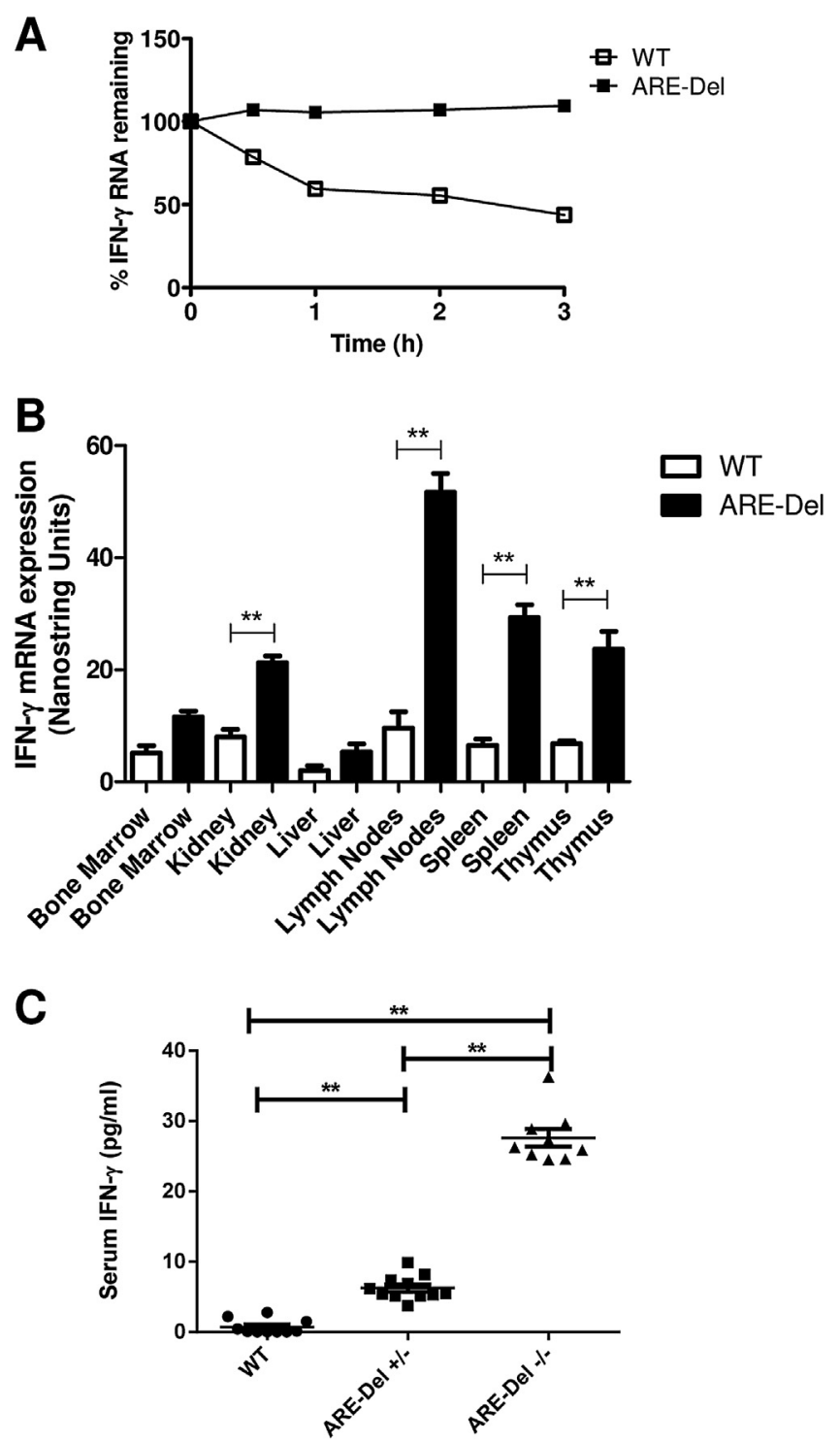

Fig. 1. IFN- $\gamma$ mRNA stabilization in ARE-Del ${ }^{-1-}$ mice. (A) Splenocytes isolated from ARE $\mathrm{Del}^{-1-}$ and WT littermate mice were placed in culture and stimulated with PMA plus ionomycin for $3 \mathrm{~h}$. Actinomycin D was added to cells and RNA was isolated at the times indicated. qPCR was performed to determine IFN- $\gamma$ and actin mRNA levels. IFN- $\gamma$ expression was normalized to actin and values plotted to calculate IFN- $\gamma$ mRNA halflife. Data was pooled from 12 individual ARE-Del ${ }^{-1-}$ and 12 WT mice. Data shown is from one of two similar experiments. (B) RNA from 4-month old ARE-Del ${ }^{-1-}$ and WT littermate mice was isolated from bone marrow, kidney, liver, lymph nodes, spleen, and thymus. RNA was hybridized to a nanostring IFN- $\gamma$ specific nCounter reporter probe and analyzed using the nCounter analysis system. Data generated were from 12 individual mice in ARE-Del ${ }^{-1-}$ and WT groups and expressed as mean \pm s.e.m. (C) Serum samples obtained from 4-month old ARE-Del ${ }^{-l-}$, ARE-Del $^{+l-}$, and WT mice were analyzed for IFN- $\gamma$ by ELISA. Data plotted are mean \pm s.e.m. from 8 individual mice per group. Statistical analysis was performed on data sets using Mann-Whitney $U$ test, ${ }^{* *} P<0.01$. 
A

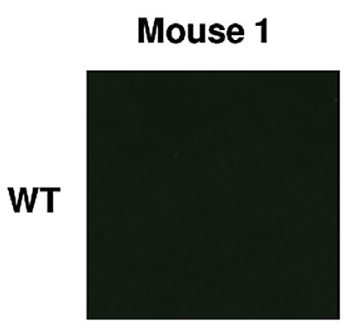

Mouse 2

Mouse 3
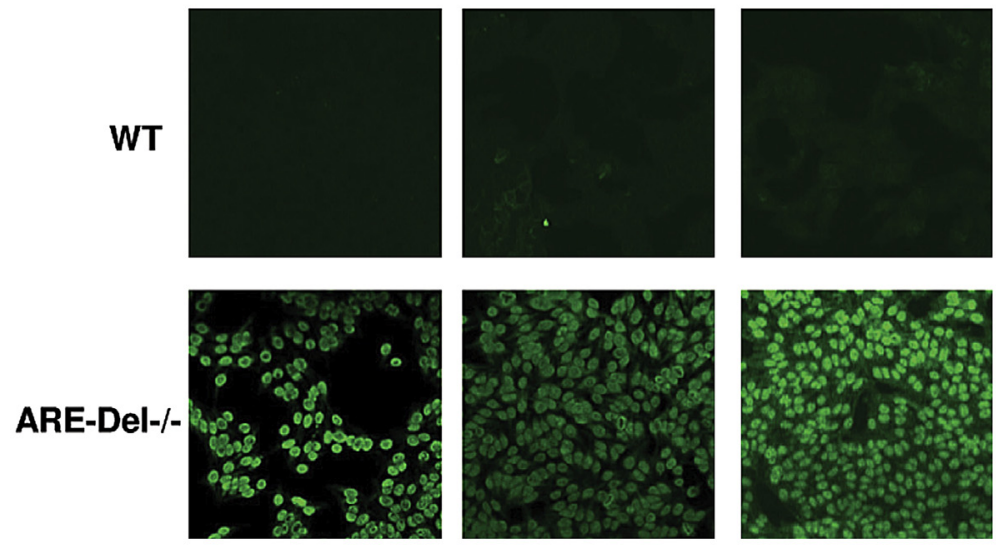

B

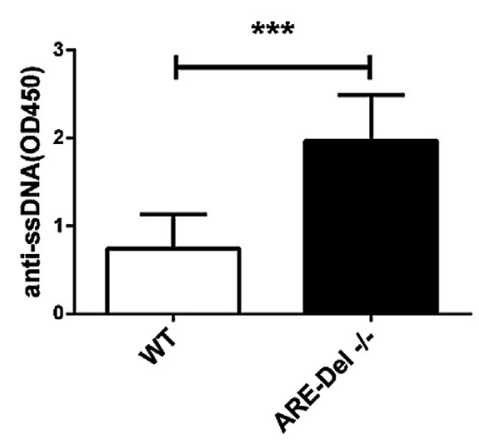

C

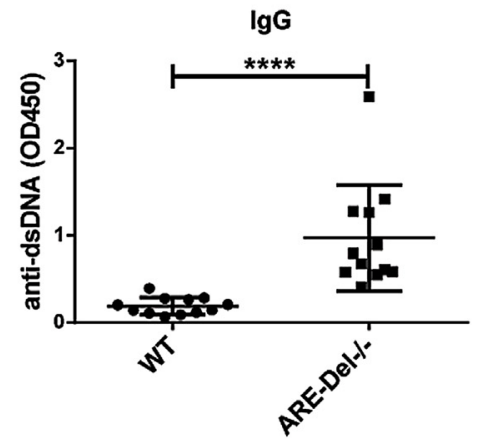

IgG2C

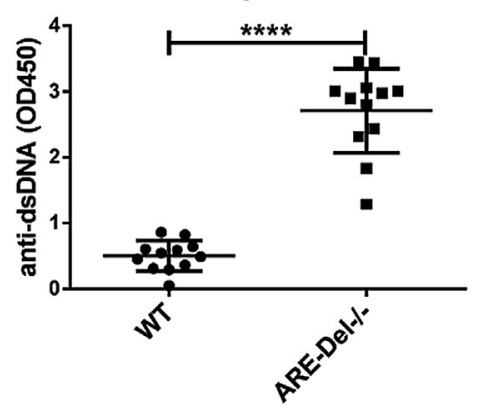

Anti-dsDNA
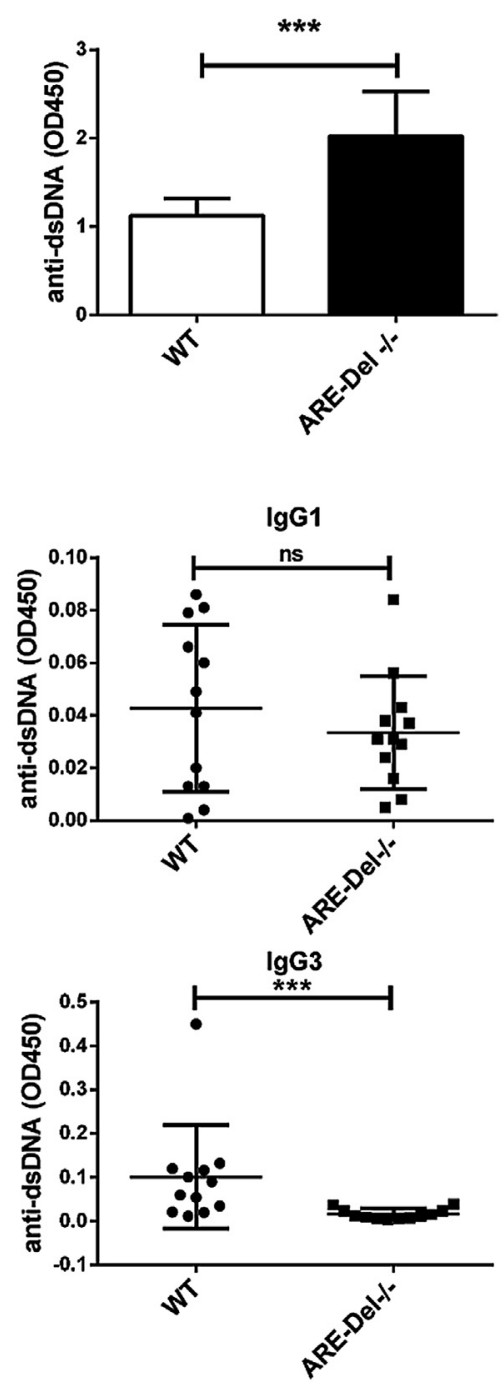

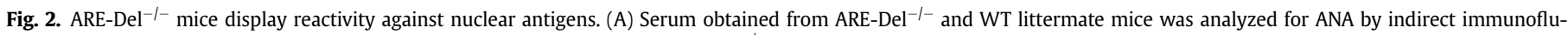

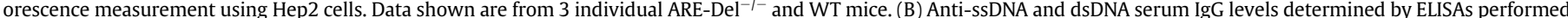

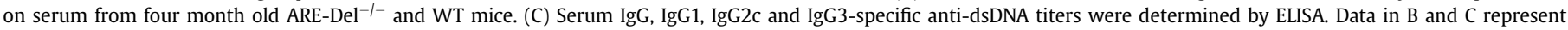
mean \pm s.e.m. for titers obtained from 11 to 12 mice per group. Statistical analysis was performed on data sets using Mann-Whitney $U$ test, ${ }^{* * *} P<0.001$. 
well-defined capillaries demonstrating moderate bilateral mesangioproliferative glomerulonephropathy in the ARE-Del ${ }^{-1-}$ mice (Fig. 3A). Pan-IgG/IgM and C3 complement staining showed increased immunoglobulin and complement deposits throughout the glomerular mesangium (Fig. $3 \mathrm{~B}$ and C). SLE-associated glomerular disease is often correlated with hypocomplementemia and in ARE-Del ${ }^{-1-}$ mice we observed a significant reduction in serum C3 complement levels (Fig. 3D). Blood urea nitrogen (BUN) levels were slight but significantly elevated in the ARE-Del ${ }^{-1-}$ mice $\left(28.02 \pm 3.4 \mathrm{mg} / \mathrm{dL}\right.$, ARE-Del $^{-1-}$ vs. $19.2 \pm 0.53 \mathrm{mg} / \mathrm{dL}$ WT $)$ demonstrating renal stress in these animals (Fig. 3E). Collectively, these data strongly demonstrate that IFN $-\gamma$ ARE deletion predisposes animals to a lupus-like syndrome with moderate renal lesions by 4 months of age.

\subsection{Chronic IFN- $\gamma$ levels impact cell populations involved in autoimmunity}

B cells and plasmacytoid dendritic cells (pDCs) are central for SLE. B cells contribute to SLE pathogenesis through both antibody-
A

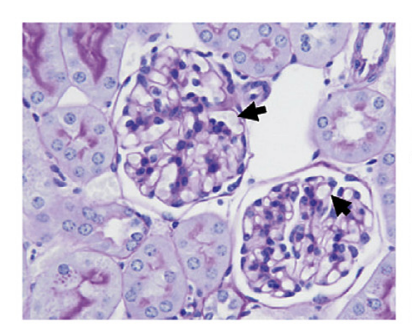

B

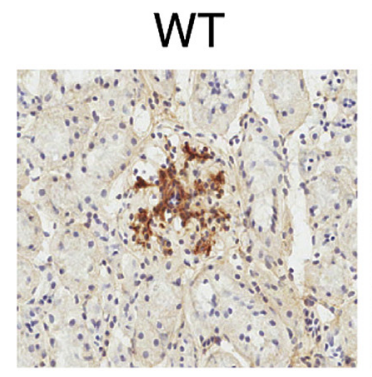

ARE-Del -/-

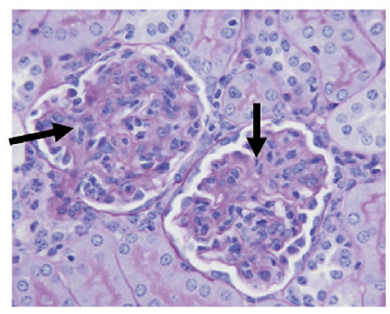

ARE-Del -/-

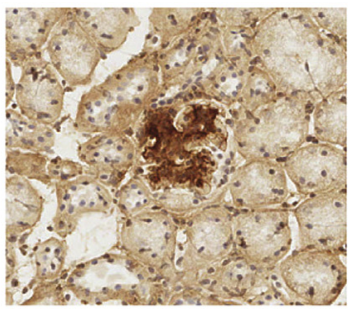

ARE-Del -/-

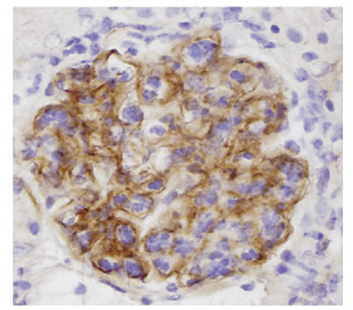

D

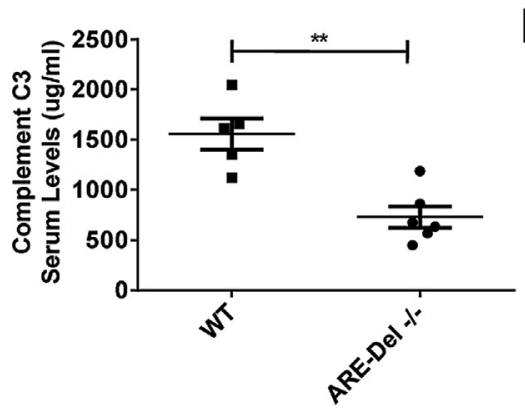

E

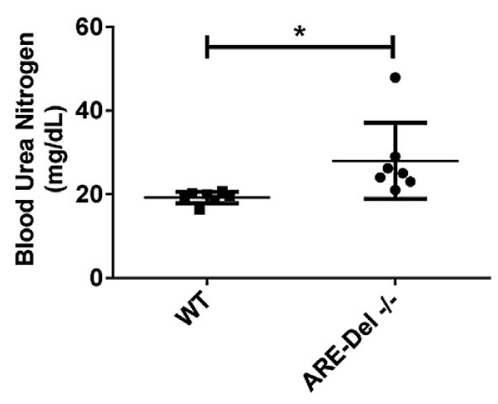

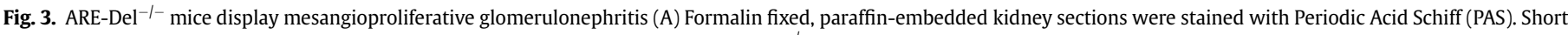

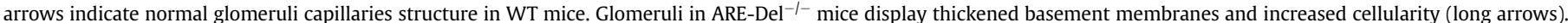

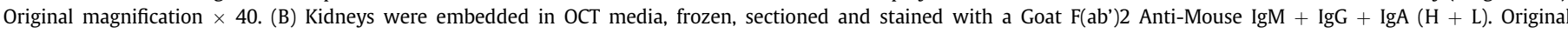

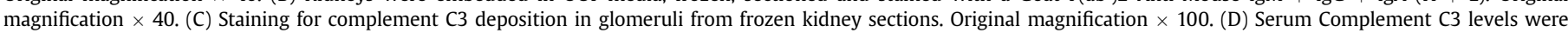

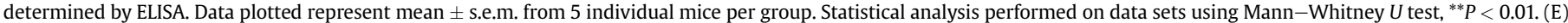

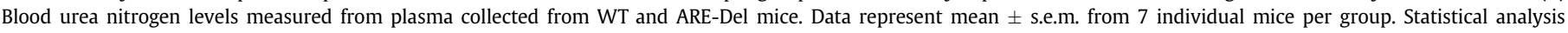
performed on data sets using unpaired Students $T$ test, ${ }^{*} P<0.05$. Histology, C3, and BUN levels were all performed on 4 month-old mice. 
dependent and -independent mechanisms. pDCs express toll-like receptors (TLRs), engage nucleic acid immune complexes, and activate signaling pathways to facilitate production and release of interferon alpha (IFN- $\alpha$ ) a factor implicated in many of the detrimental effects in SLE.

ARE-Del ${ }^{-1-}$ mice have a significant increase in the percentage and absolute number of pDCs cells in bone marrow and spleen relative to WT mice (Fig. 4A and Supplemental Fig. 6A). This correlates with increased serum Flt3L concentration in ARE-Del ${ }^{-1-}$ mice (Supplemental Fig. 6B) and increased IFN- $\alpha$ production following TLR7 agonist addition to ARE-Del ${ }^{-1-}$ cultured splenocytes (Supplemental Fig. 6C). To determine if IFN- $\gamma$ plays a role in pDC development, bone marrow cells from ARE-Del ${ }^{-1-}$ and WT mice were cultured in the presence of Flt3L and IFN- $\gamma$ and after 9 days,
A

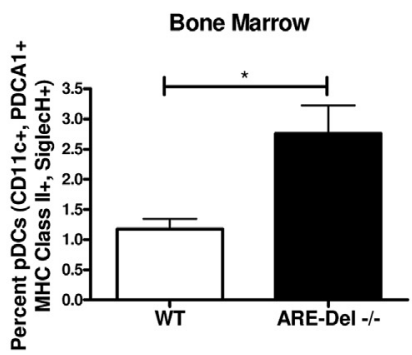

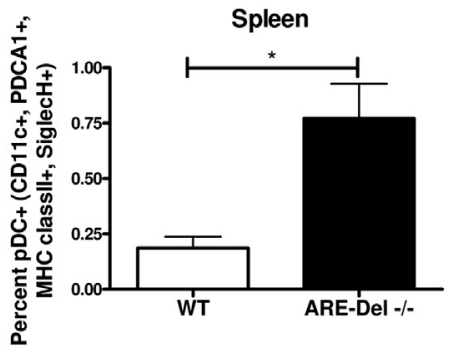

B

WT
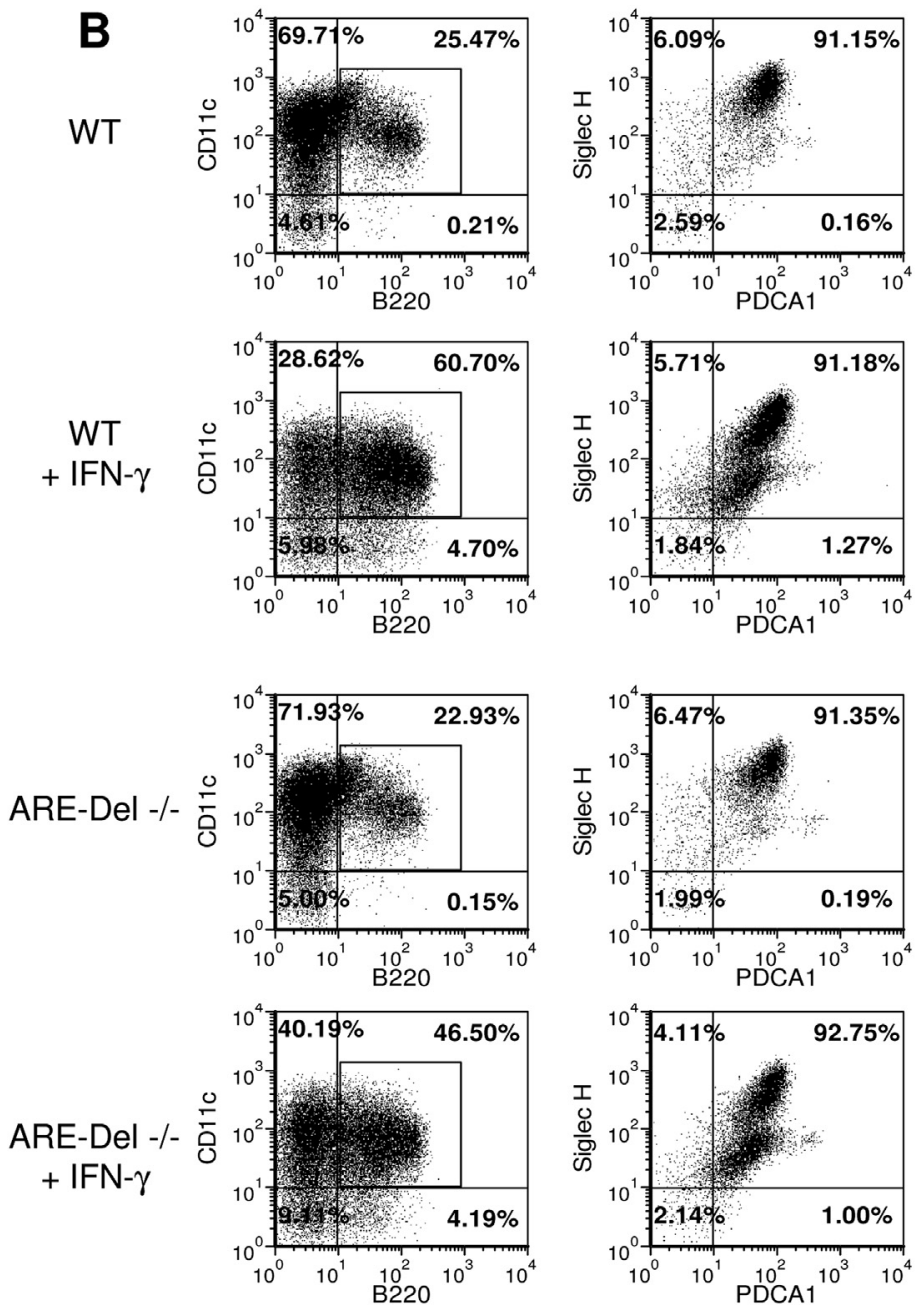

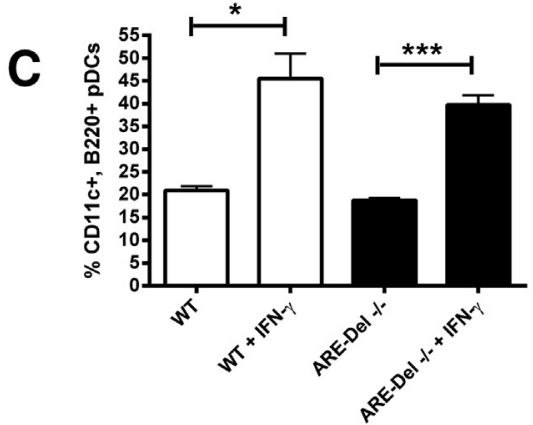

D
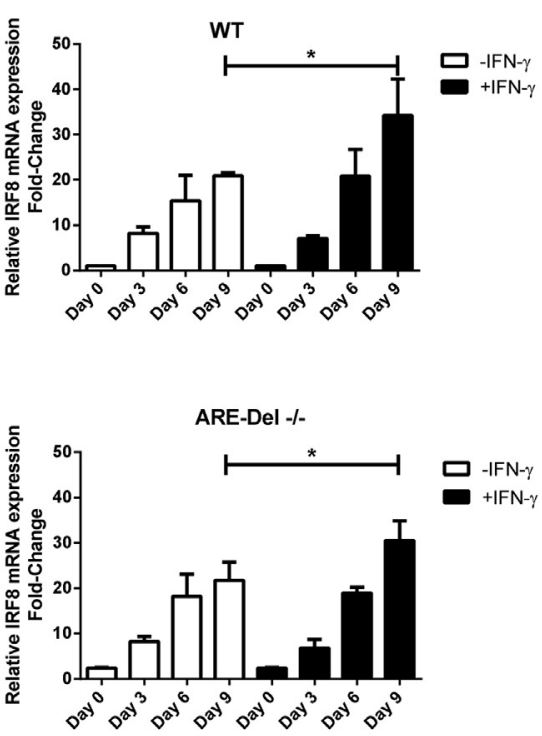

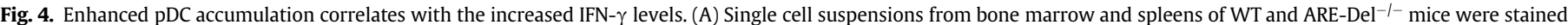

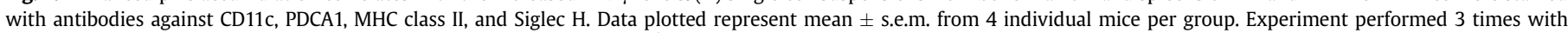

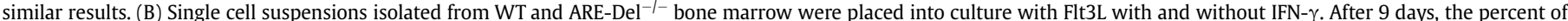

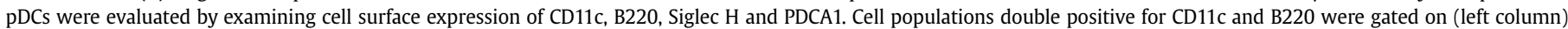

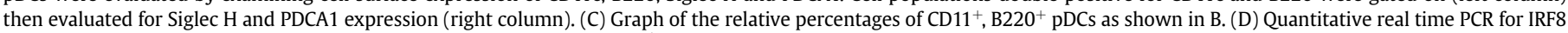

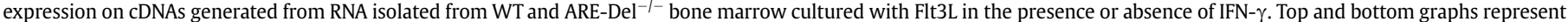

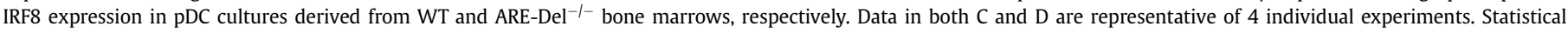
analysis performed on data sets using unpaired Students $T$ test, ${ }^{*} P<0.05$; ${ }^{* * *} P<0.001$. 
IFN- $\gamma$ increased the percentage of pDCs in both the ARE-Del ${ }^{-1-}$ and WT populations by approximately 2-fold (Fig. 4B and C). Surprisingly, in the absence of exogenously added IFN $-\gamma$, WT and ARE$\mathrm{Del}^{-l-}$ bone marrow cultures produced similar, lower percentages of pDCs suggesting that constant IFN- $\gamma$ exposure is required to enhance pDC development (Fig. 4B and C).

pDC Lineage commitment is dependent on E2-2 and IRF8 transcription factors [35]. IRF8 is best known as an IFN- $\gamma$ inducible factor [36] involved in lineage development of hematopoietic cells types including macrophages and B cells [37,38]. To ask if IFN- $\gamma$ affects E2-2 and IRF8 expression, we examined the relative mRNA expression of these factors at different days following Flt3L and IFN- $\gamma$ addition to bone marrow cultures. At day 0, IRF8 mRNA levels were low in WT and ARE-Del ${ }^{-1}$ cultures; however, basal IRF8 mRNA levels were slightly elevated in ARE-Del ${ }^{-1-}$ cells (Fig. 4D). By day 9, both WT and ARE-Del ${ }^{-1-}$ cultures treated with IFN- $\gamma$ displayed a 30-40-fold increase in IRF8 mRNA whereas cultures without IFN- $\gamma$ had only an approximately 20 -fold increase. Since E2-2 can directly augment IRF8 expression, we asked if IFN- $\gamma$ could differentially enhance E2-2 mRNA levels and found that E2-2 mRNA levels were similar in WT bone culture irrespective of IFN- $\gamma$ addition (Supplemental Fig. 6D). In contrast, the IFN- $\gamma$-treated AREDel $^{-1-}$ bone marrow culture expressed 50\% less E2-2 mRNA by day 9 (Supplemental Fig. 6D) suggesting that IFN- $\gamma$ enhances pDC development in an IRF8 dependent manner that does not require E2-2. Further work is needed to identify other transcription factors involved in pDC development in response to IFN- $\gamma$.

To determine if the increase in pDCs was specific or represented a general change in dendritic cell populations in the ARE-Del ${ }^{-1}$ mice, we examined the level of conventional dendritic cells (cDCs) in spleen. The percent of spleen CD11 $c^{\text {high }}$, MHC class II ${ }^{\text {high }}$ cDCs was not significantly different between ARE-Del ${ }^{-1-}$ and WT mice (Fig. 5A and C). When the $\mathrm{CDC}$ population was further segregated into $\mathrm{CD} 4^{+} \mathrm{CD} 8^{-} \mathrm{cDCs}\left(\mathrm{CD} 4^{+} \mathrm{cDCs}\right)$, double negative $\mathrm{CD} 4^{-} \mathrm{CD} 8^{-} \mathrm{cDCs}$ (DN cDCs), and $\mathrm{CD}^{-} \mathrm{CD}^{+} \mathrm{cDCs}\left(\mathrm{CD}^{+} \mathrm{cDCs}\right)$ there was no difference in the $\mathrm{CD}^{+} \mathrm{CDC}_{\text {populations between the WT and ARE-Del }}{ }^{-1-}$ mice (Fig. 5B and D). Yet, an inverse relationship with regard to $\mathrm{CD}^{+}{ }^{+} \mathrm{cDCs}$ and DN cDCs between the WT and ARE-Del ${ }^{-1-}$ mice was
A
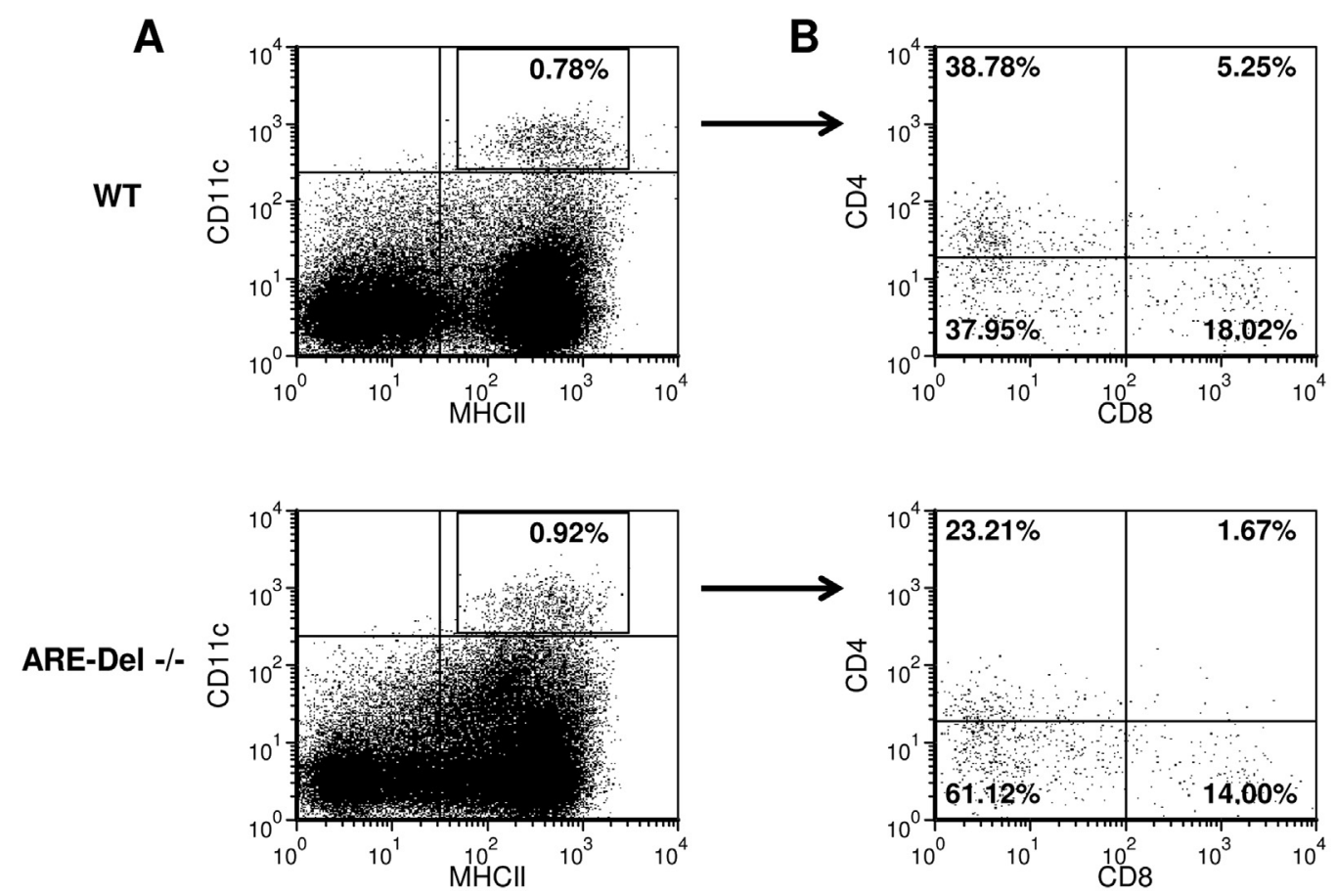

C

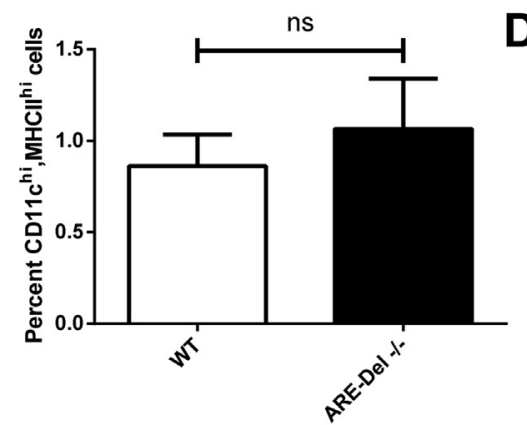

D

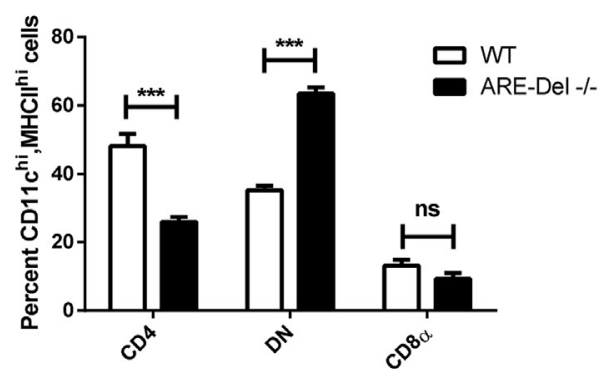

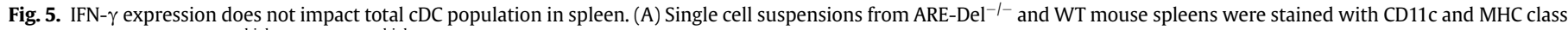

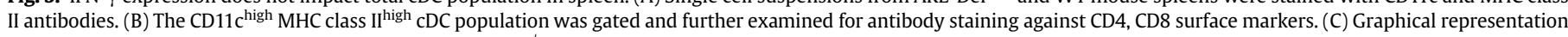

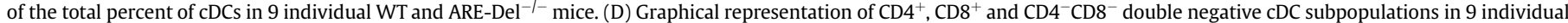

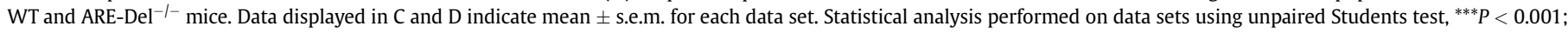
ns, not significant. 
observed (Fig.. 5B and D). WT mice had approximately equal percentages of both DN cDCs and CD4 ${ }^{+} \mathrm{cDCs}(38 \%)$ whereas ARE-Del ${ }^{-1}$ - mice had $61 \% \mathrm{DN}$ cDCs and $23 \% \mathrm{CD}^{+}$cDCs. These data suggest that the overall $\mathrm{CDC}$ population is not affected by IFN $-\gamma$ expression and further supports a cell-specific role for IFN- $\gamma$ in pDC development. However, it is interesting that some cDC subpopulations are altered. How this effects the biology of the ARE-Del ${ }^{-1-}$ animals has not been determined.

Examination of bone marrow $B$ cells indicated no significant differences between ARE-Del ${ }^{-1-}$ and WT mice (Fig. 6A). Yet, in ARE$\mathrm{Del}^{-1-}$ spleen, there was an approximate 20 percent reduction in the total $\mathrm{B} 220^{+}, \mathrm{CD} 19^{+}$cell population (Fig. 6B) with a concurrent increase in $\mathrm{B}^{2} 20^{+}, \mathrm{CD} 19^{+}$cells in lymph nodes (Supplemental Fig. 7) that was possibly due to increased B cell trafficking to this tissue. In spite of the total B cell decrease the percent of $\mathrm{CD}^{+} 5^{+}$, $\mathrm{GL7}^{+}$germinal center (GC) B cells increased (Fig. 6C), an observation consistent with increased autoantibody production and lupuslike disease. The ARE-Del ${ }^{-1-} \mathrm{B}$ cell population expressed CD80 and CD86 activation markers (Fig. 6C) and closer examination of this population indicated no change in $\mathrm{CD} 23^{\mathrm{hi}}, \mathrm{CD} 21^{\mathrm{lo}}$ follicular B cell subset. However, the percentage of $\mathrm{CD} 23^{\text {null }}, \mathrm{CD} 21^{\text {hi }}$ marginal zone B (MZB) cells was greatly reduced or absent (Fig. 6C).

\subsection{ARE-Del mice lose MZMs and develop autoimmunity}

The spleen marginal zone represents the boundary between the lymphoid white pulp and erythrocyte-rich red pulp and is resident to both MZB cells and marginal zone macrophages (MZMs). As
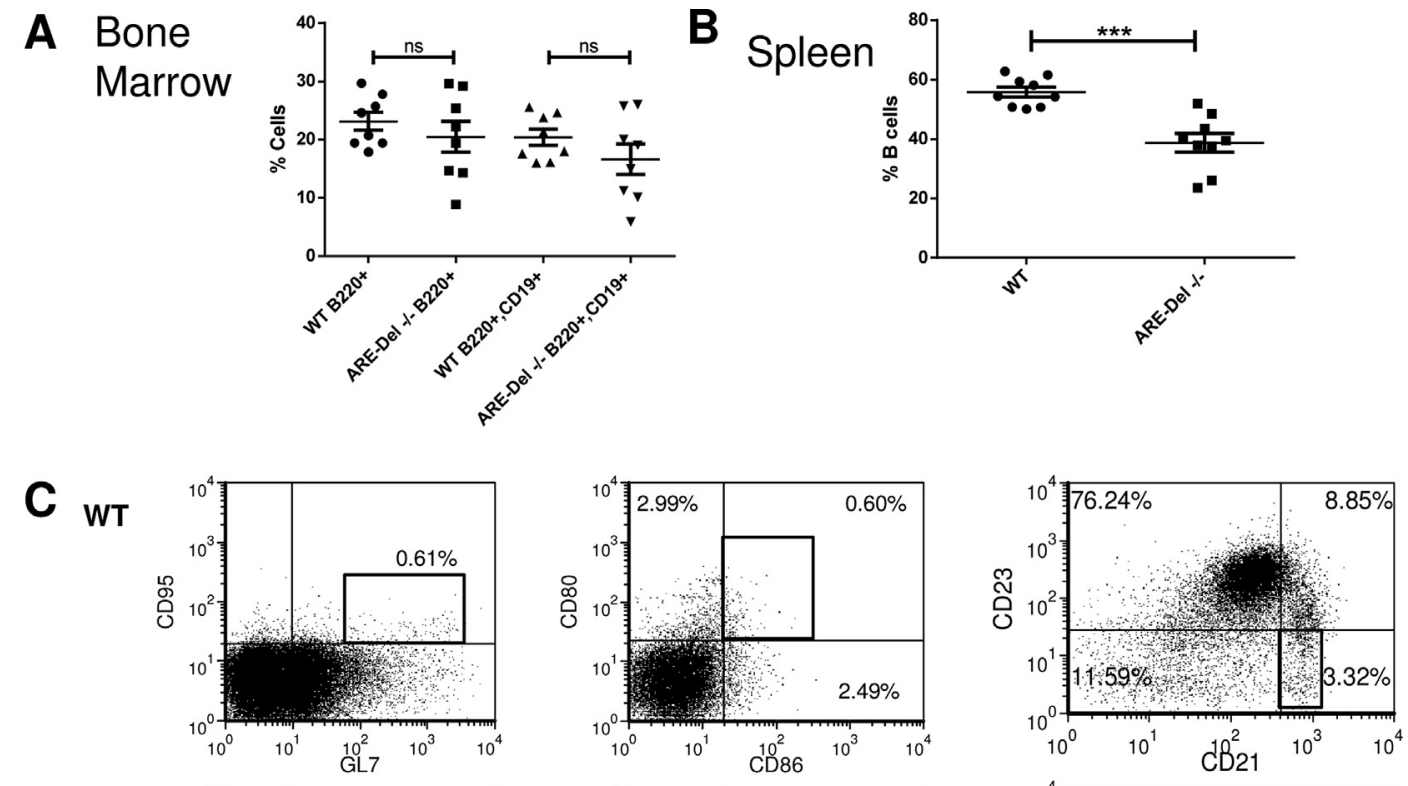

ARE-Del
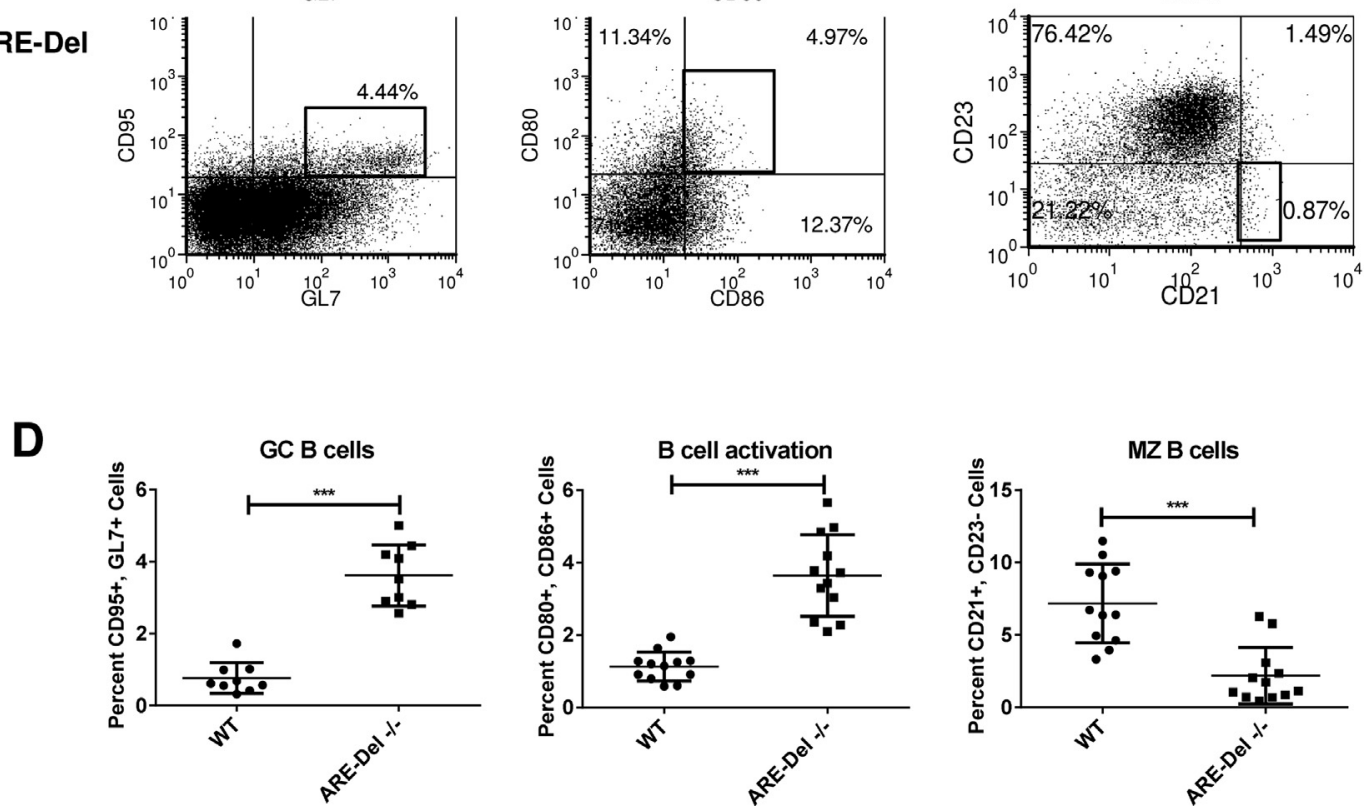

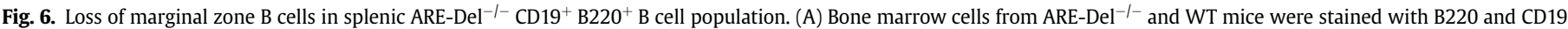

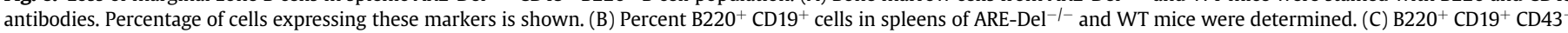

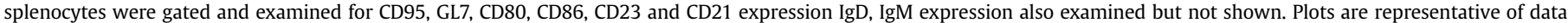

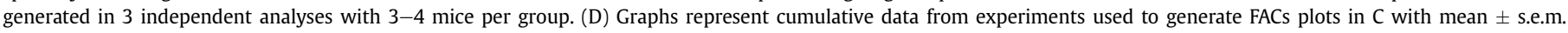
provided for each data set. Statistical analysis performed on data sets using Mann-Whitney $U$ test, ${ }^{* * *} P<0.001$; ns, not significant. 
these cells are functionally and developmentally interdependent $[39,40]$, severe reductions in MZB cells could place spleen MZM development and residence in jeopardy. Confocal microscopy of $\mathrm{ARE}^{-\mathrm{Del}^{-1-}}$ mouse spleen showed a reorganization of the splenic cellular compartments with ill-defined B and T cells zones, F4/80 red pulp macrophages present, but an absence of $\mathrm{CD}_{169}{ }^{+}, \mathrm{MARCO}^{+}$ MZMs (Fig. 7). MZMs have been shown to play a role in removal of endogenous apoptotic cells to prevent autoimmune responses [41]. This is consistent with heterozygous ARE-deletion (ARE-Del ${ }^{+/-}$) mice that partially retain their MZBs and MZMs (Fig. 8A) and have either no or very weak autoimmune effects as demonstrated by only a slight but non-significant elevation in anti-DNA antibody levels (Fig. 8B). Because of this, we asked if selective MZMs removal would induce these animals to become more sensitive to "self" and develop autoimmune symptoms similar to the ARE-Del ${ }^{-1-}$ mice. WT and ARE-Del ${ }^{+/-}$mice were injected once weekly with $167 \mu \mathrm{g}$ clodronate, a dosage that eliminates MZMs but allows red pulp macrophages to remain [41]. After 12 weeks, mice were examined for loss of MZMs, serum anti-DNA antibodies, and kidney lesions. Confocal imaging demonstrated that the low dose clodronate selectively removed the MZMs (Fig. 8A) and was concomitant with a significant increase in anti-DNA antibody levels in the clodronate treated ARE-Del ${ }^{+/-}$mice as compared to clodronate-treated WT and liposome-injected control ARE-Del ${ }^{+/-}$mice (Fig. 8C). Kidney lesions were evident in both the control and clodronate-treated ARE-Del $^{+/}$and was likely due to chronic exposure to circulating IFN- $\gamma$. However, clodronate-treated ARE-Del ${ }^{+/-}$mice displayed increased immunoglobulin deposits, lymphocytic infiltrates and a more severe mesangioproliferative glomerulopathy (Fig. 8D, Supplemental Fig. 8, Supplemental Table 2) suggesting an increase in autoimmune-related tissue destruction.

\section{Discussion}

Our current work has focused on consequences of disrupted IFN- $\gamma$ posttranscriptional control through deletion of a multi-ARE RNA regulatory region in the IFN $-\gamma 3^{\prime}$ UTR. AREs are associated with RNA destabilization and we predicted that removal of five AREs in the IFN $-\gamma 3^{\prime}$ UTR would stabilize the IFN $-\gamma$ mRNA. Indeed we observed a dramatic increase in IFN- $\gamma$ mRNA half-life that translated into chronic low levels of circulating IFN $-\gamma$ in mice.

The syndrome in ARE-Del ${ }^{-1-}$ mice develops by 16 weeks of age and is similar to human SLE in that it manifests itself by autoantibody production and renal glomerulopathy. Autoantibody production in 8-week old ARE-Del ${ }^{-1-}$ mice shows similarity to human SLE in that autoantibodies are often detected well in advance of clinical disease onset [30]. Moreover, elevated autoantibodies correlate with neutrophilia in both the ARE-Del ${ }^{-1-}$ model and in human SLE which, in turn, plays a role in vascular breakdown, and lupus nephritis [29].

pDCs are uniquely suited to promote SLE development because of restricted TLR-7 and -9 expression patterns [42] and the capacity to produce elevated IFN- $\alpha$ levels [43]. Our finding that ARE-Del ${ }^{-/-}$ bone marrow had increased pDC numbers was unexpected. The molecular basis for bone marrow pDC lineage commitment is dependent upon multiple transcription factors and their relative expression levels. IRF-8 is an important transcription factor in pDC development as demonstrated by pDC loss in IRF8 deficient mice and in vitro Flt-3L treated bone marrow cultures from IRF-8 deficient mice $[44,45]$. Our study found that IRF8 mRNA expression was significantly increased in bone marrow pDC cultures treated with IFN- $\gamma$. Moreover, cells from both WT and ARE-Del ${ }^{-1-}$ bone marrow responded similarity to IFN $-\gamma$ stimulation suggesting that IFN- $\gamma$

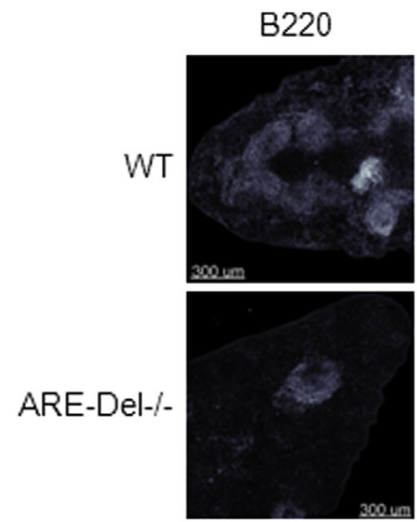

$\mathrm{B} 220$
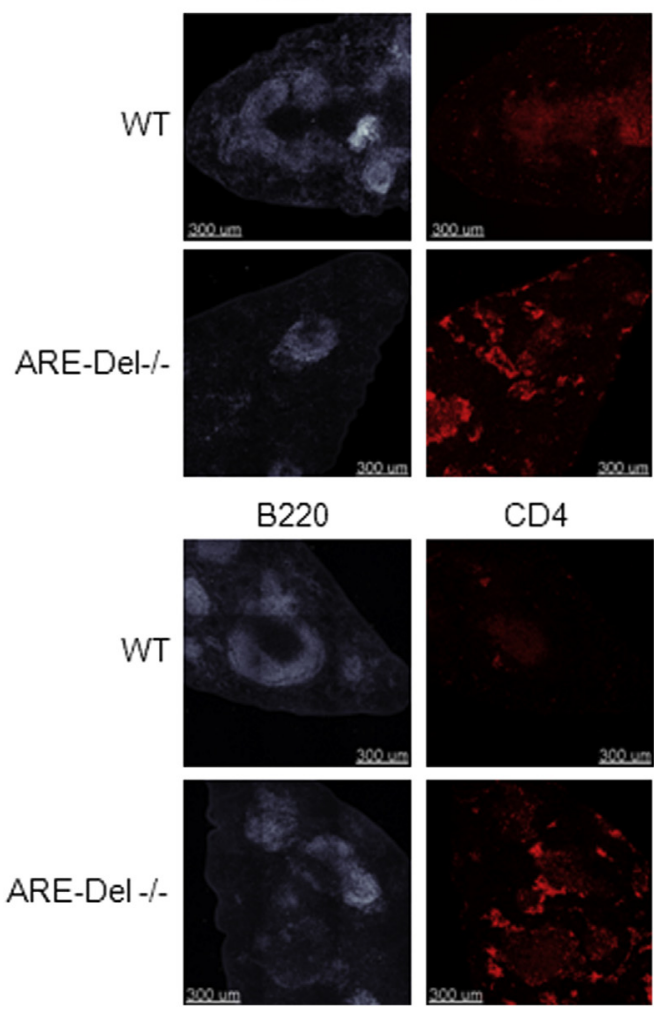

CD4
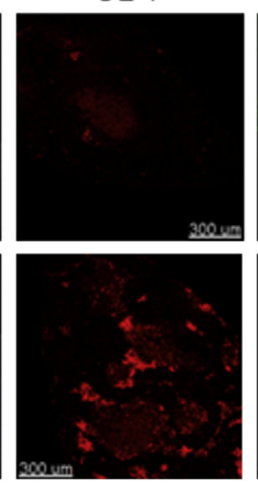

CD169
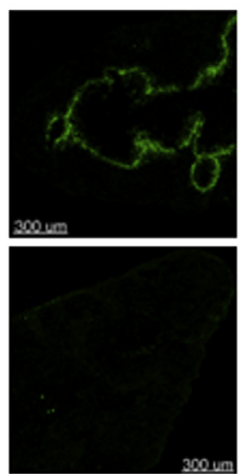

MARCO
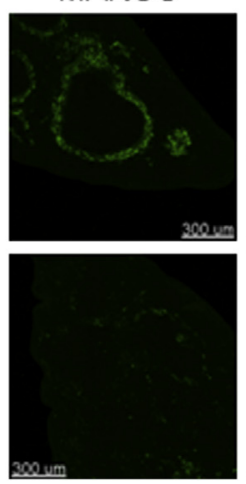

$\mathrm{F} 4 / 80$

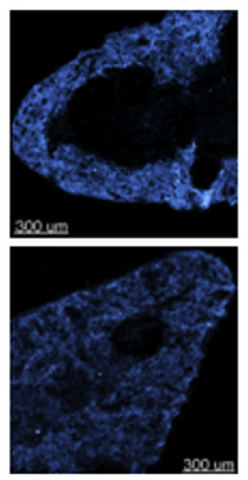

$\mathrm{F} 4 / 80$
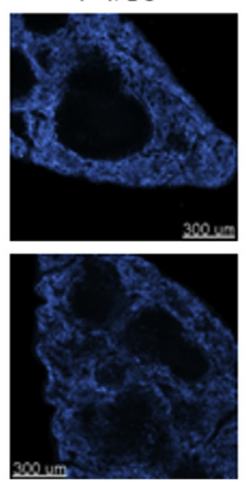

Merged

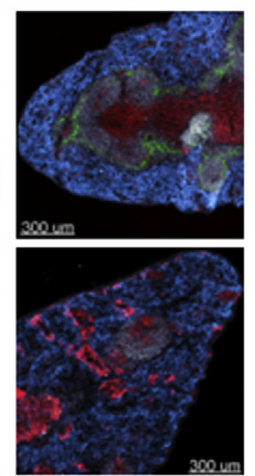

Merged
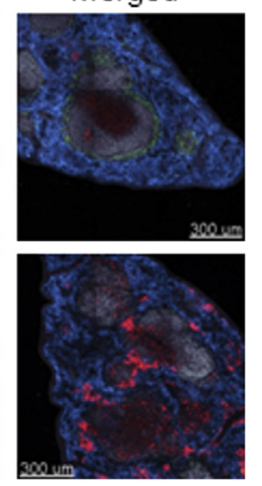

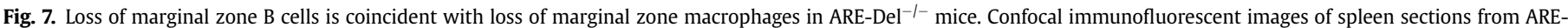

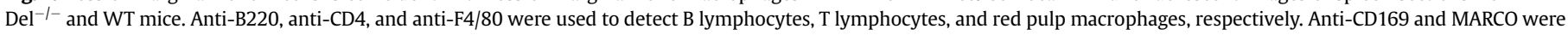
used for marginal zone macrophage detection. White bars on images represent $300 \mu \mathrm{m}$. 


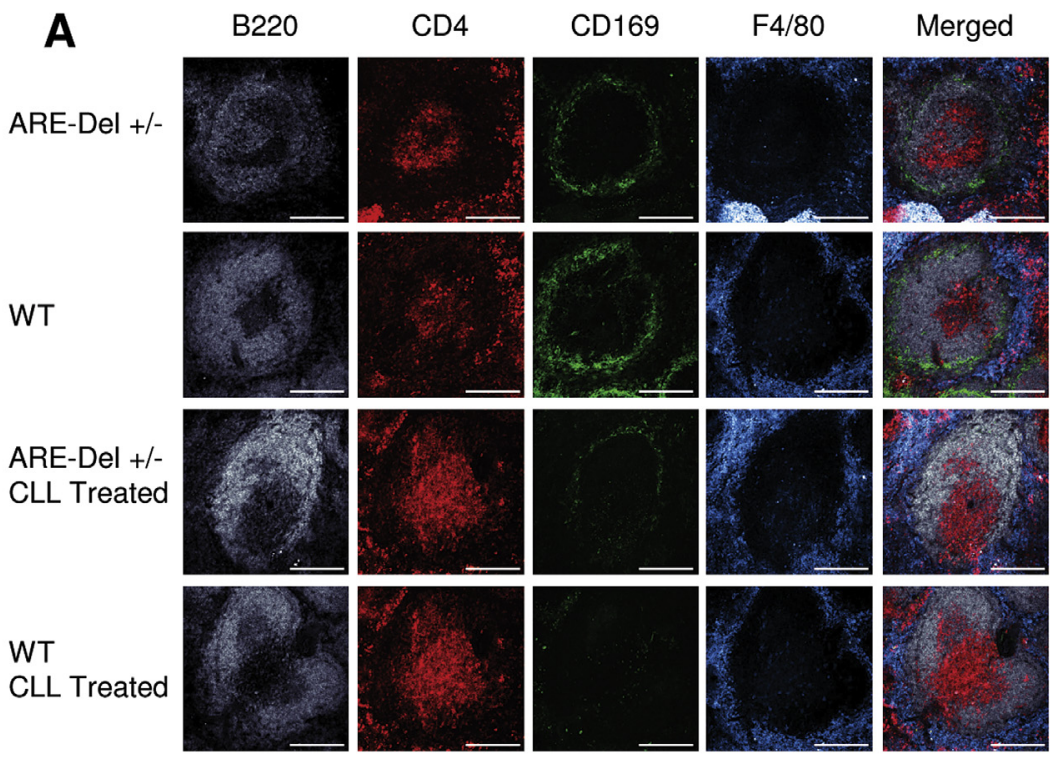

B

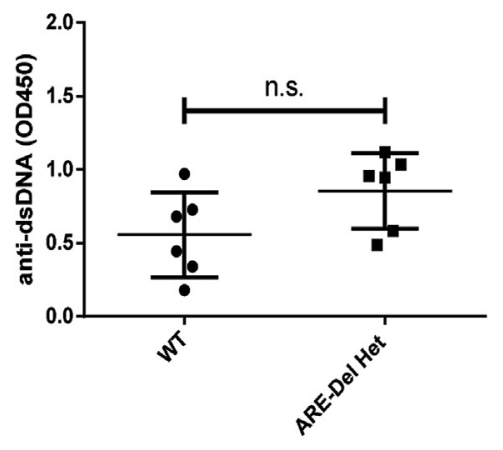

D

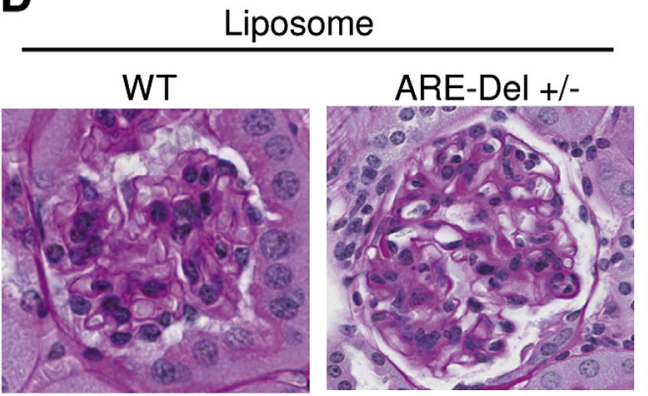

C

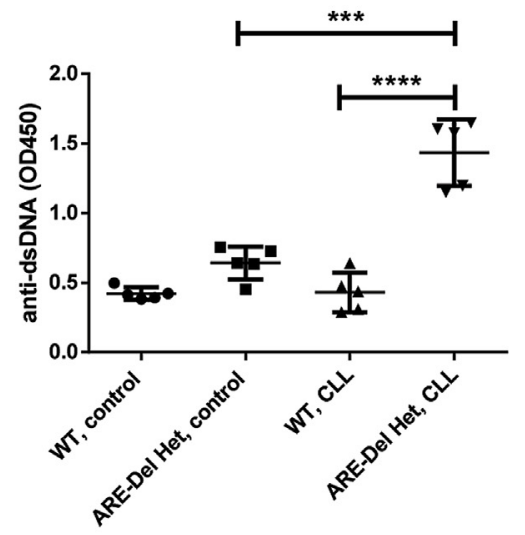

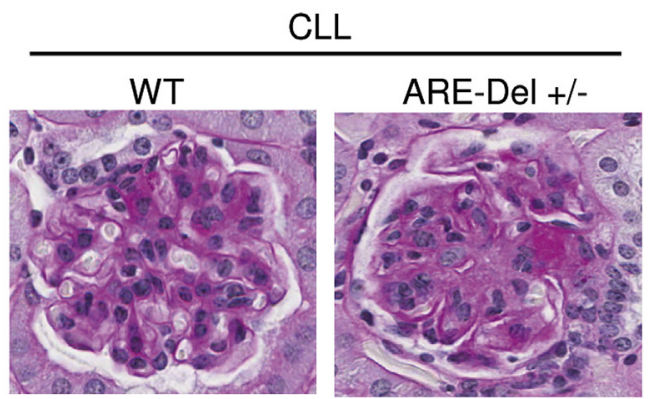

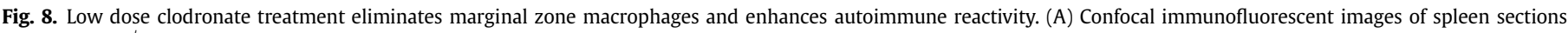

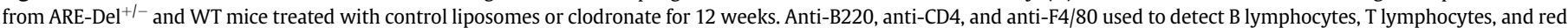

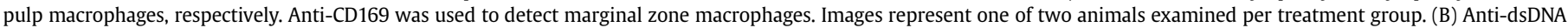

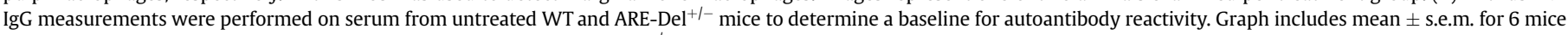

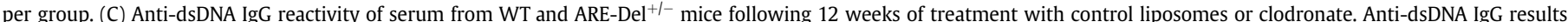

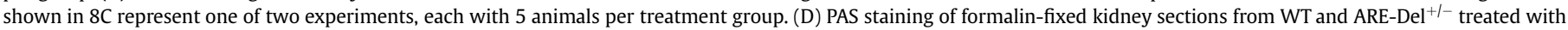

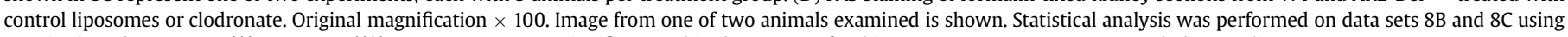
unpaired Students $T$ test, ${ }^{* * *} P<0.001$; ${ }^{* * * *} P<0.0001$; ns, not significant. White bars on confocal images represent $300 \mu$ m. CLL, clodronate lipsomes.

pre-exposure in ARE-Del ${ }^{-1-}$ mice was not a prerequisite for response or magnitude of response to IFN- $\gamma$. E2-2 is central to pDC development as illustrated by the absence of pDCs from E2-2 deficient hematopoietic progenitors [35]. Interestingly, E2-2 has been shown to bind to Irf8 promoter [35] suggesting that IRF8 expression is downstream of E2-2. Our study found that E2-2 expression is present but not altered in ARE-Del ${ }^{-1-}$ mice. Thus, IFN- $\gamma$ may eliminate the need for enhanced E2-2 levels and instead, via-IRF8, aid E2-2 to push pDC gene expression.

The marginal zone is a highly specialized structure that allows innate and adaptive immune cells to interact in response to pathogens. Resident MZB cells are positioned in close proximity to 
specialized MZMs that express both MARCO and CD169 receptors and act as phagocytic cells for clearance of blood-borne pathogens and apoptotic materials. Additionally, MZB cells are required for normal marginal zone development as well as the presence and function of MZMs [40]. The lack of MZB cells in ARE-Del ${ }^{-1-}$ mice lead us to ask if the MZM population was altered and indeed we observed a complete MZM absence in homozygote but not heterozygote mice. As recently shown, elimination of MZMs promotes autoimmunity onset in WT mice injected with apoptotic cells [41]. This led us to ask whether ARE-Del ${ }^{+/-}$mice, that retain MZB and MZMs and are resistant to autoimmunity, could be pushed to an autoimmune state. We performed a low-dose clodronate injection regiment and found autoantibody development as well as glomerulonephritis in ARE-Del ${ }^{+/-}$mice. In contrast to WT mice, ARE-Del $^{+/-}$mice did not require injection of apoptotic cells. This suggested that chronic low IFN- $\gamma$ levels may be effective for apoptosis incidence; however, the mechanism and susceptible cell types is currently not known. IFN- $\gamma$ induces apoptosis in a variety of cells so it is not without precedence that low chronic levels of IFN- $\gamma$ could promote autoimmunity through increased inflammatory states, cellular disruption and imbalanced homeostasis in immune tissues.

The conserved ARE controls IFN- $\gamma$ expression by altering IFN- $\gamma$ mRNA half-life; yet the molecular mechanism responsible for this is not entirely understood. Work by Ogilvie et al. provided evidence for tristetraprolin (TTP) control of IFN- $\gamma$ expression through TTP binding to an 18 nucleotide region in the conserved IFN- $\gamma$ ARE region. Additionally, they showed that IFN- $\gamma$ mRNA and protein were elevated in TTP knockout mice [14]. Our laboratory has identified a miRNA binding site $3^{\prime}$ to the IFN- $\gamma$ ARE-sequence that, by SHAPE analysis [46], is spatially close to the TTP binding region. Interestingly, miRNA binding to this sequence stabilizes IFN- $\gamma$ mRNA. The proximity of the TTP and miRNA binding sites make it plausible that proteins associated with miRNA binding may occlude TTP binding and block subsequent destabilization of IFN- $\gamma$ mRNA (Savan, R. et al. manuscript submitted). Another possibility is that certain cytokines may trigger events leading to the inactivation of TTP interactions with IFN $-\gamma$ mRNA. Previous work by our laboratory has shown that IL-12 mediates perinuclear accumulation of IFN- $\gamma$ mRNA [11]. IL-12 partially controls IFN- $\gamma$ expression through p38 MAPK that in turn, activates the downstream kinase MK2. MK2 is an important mediator of posttranscriptional control by direct phosphorylation and inactivation of TTP, resulting in mRNA stabilization [47]. Thus, it is intriguing to hypothesize that IL-12 may alter IFN- $\gamma$ mRNA stability and localization by the actions of MK2 on TTP. This may result in enhanced miRNA/IFN- $\gamma$ mRNA binding that ultimately associates the complex with the nuclear membrane. Ribonuclear protein(s) involved in such a mechanism are unknown and a better understating of how ARE elements, miRNAs and RNA-binding proteins coordinate IFN- $\gamma$ expression is currently under investigation in our laboratory.

\section{Conclusions}

Our findings demonstrate that small alterations in the IFN- $\gamma$ signaling pathway lead to detrimental systemic outcomes in host immune physiology and response that is dependent upon crossing a "threshold" level of circulating IFN- $\gamma$. Thus, the need for multifaceted control of IFN- $\gamma$ expression is imperative for proper immune function and well-being. The ARE-Del ${ }^{-1-}$ mouse highlights this point demonstrating a connection between uncontrolled low IFN- $\gamma$ levels and autoimmunity and suggest that a therapeutic blockade of the IFN- $\gamma$ signaling pathway may provide an effective treatment for autoimmunity and in particular SLE.

\section{Authorship contributions}

D.L. H. and H.A.Y. designed and performed experiments and wrote manuscript.

C. B., V.C., and W. K. designed and performed experiments.

M.D. B., P. M. S., H. S., A J. S., J.J. S., M. R. A., J. R. O., F. L., D. A. R., M.E. S, performed experiments.

P. K., L. T, and D. M. K., provided intellectual input and manuscript review.

\section{Funding}

This project has been funded in part with funds from the National Cancer Institute, National Institutes of Health, under Contract No. HHSN261200800001E.

\section{Disclosure}

The authors declare no competing financial interests.

\section{Acknowledgments}

We thank Grace Williams, John Wine, Megan Karwan, Bill Bere and Catherine Razzook for technical assistance, animal breeding, and experiments. Dr. Daniel McVicar and Dr. Giorgio Trinchieri for helpful comments and manuscript review.

\section{Appendix A. Supplementary data}

Supplementary data related to this article can be found at http:// dx.doi.org/10.1016/j.jaut.2014.02.003.

\section{References}

[1] Seery JP, Carroll JM, Cattell V, Watt FM. Antinuclear autoantibodies and lupus nephritis in transgenic mice expressing interferon gamma in the epidermis. J Exp Med 1997;186:1451-9.

[2] Lee SK, Silva DG, Martin JL, Pratama A, Hu X, Chang PP, et al. Interferongamma excess leads to pathogenic accumulation of follicular helper $\mathrm{T}$ cells and germinal centers. Immunity 2012;37:880-92.

[3] Peng SL, Moslehi J, Craft J. Roles of interferon-gamma and interleukin-4 in murine lupus. J Clin Invest 1997;99:1936-46.

[4] Harigai M, Kawamoto M, Hara M, Kubota T, Kamatani N, Miyasaka N. Excessive production of IFN-gamma in patients with systemic lupus erythematosus and its contribution to induction of B lymphocyte stimulator/B cell-activating factor/TNF ligand superfamily-13B. J Immunol 2008;181:2211-9.

[5] Kim K, Cho SK, Sestak A, Namjou B, Kang C, Bae SC. Interferon-gamma gene polymorphisms associated with susceptibility to systemic lupus erythematosus. Ann Rheum Dis 2010;69:1247-50.

[6] Henriques A, Teixeira L, Ines L, Carvalheiro T, Goncalves A, Martinho A, et al. NK cells dysfunction in systemic lupus erythematosus: relation to disease activity. Clin Rheumatol 2013;32:805-13.

[7] Masutani K, Akahoshi M, Tsuruya K, Tokumoto M, Ninomiya T, Kohsaka T, et al. Predominance of Th1 immune response in diffuse proliferative lupus nephritis. Arthritis Rheum 2001;44:2097-106.

[8] Shah D, Kiran R, Wanchu A, Bhatnagar A. Oxidative stress in systemic lupus erythematosus: relationship to Th1 cytokine and disease activity. Immunol Lett 2010;129:7-12.

[9] Davidson A. The rationale for BAFF inhibition in systemic lupus erythematosus. Curr Rheumatol Rep 2012;14:295-302.

[10] Schoenborn JR, Wilson CB. Regulation of interferon-gamma during innate and adaptive immune responses. Adv Immunol 2007:96:41-101.

[11] Hodge DL, Martinez A, Julias JG, Taylor LS, Young HA. Regulation of nuclear gamma interferon gene expression by interleukin 12 (IL-12) and IL-2 represents a novel form of posttranscriptional control. Mol Cell Biol 2002;22: $1742-53$.

[12] Ma F, Xu S, Liu X, Zhang Q, Xu X, Liu M, et al. The microRNA miR-29 controls innate and adaptive immune responses to intracellular bacterial infection by targeting interferon-gamma. Nat Immunol 2011;12:861-9.

[13] Steiner DF, Thomas MF, Hu JK, Yang Z, Babiarz JE, Allen CD, et al. MicroRNA-29 regulates $\mathrm{T}$-box transcription factors and interferon-gamma production in helper T cells. Immunity 2011;35:169-81. 
[14] Ogilvie RL, Sternjohn JR, Rattenbacher B, Vlasova IA, Williams DA, Hau HH, et al. Tristetraprolin mediates interferon-gamma mRNA decay. J Biol Chem 2009;284:11216-23.

[15] Wang JG, Collinge M, Ramgolam V, Ayalon O, Fan XC, Pardi R, et al. LFA-1dependent HuR nuclear export and cytokine mRNA stabilization in T cell activation. J Immunol 2006;176:2105-13.

[16] Kontoyiannis D, Pasparakis M, Pizarro TT, Cominelli F, Kollias G. Impaired on/ off regulation of TNF biosynthesis in mice lacking TNF AU-rich elements: implications for joint and gut-associated immunopathologies. Immunity 1999; 10:387-98.

[17] Copeland NG, Jenkins NA, Court DL. Recombineering: a powerful new tool for mouse functional genomics. Nat Rev Genet 2001;2:769-79.

[18] Kastenmuller W, Torabi-Parizi P, Subramanian N, Lammermann T, Germain RN. A spatially-organized multicellular innate immune response in lymph nodes limits systemic pathogen spread. Cell 2012;150:1235-48.

[19] Dong L, Ito S, Ishii KJ, Klinman DM. Suppressive oligodeoxynucleotides delay the onset of glomerulonephritis and prolong survival in lupus-prone NZB NZW mice. Arthritis Rheum 2005;52:651-8.

[20] Kulkarni MM. Digital multiplexed gene expression analysis using the NanoString nCounter system. Curr Protoc Mol Biol; 2011. Chapter 25:Unit25B.

[21] Carlucci F, Cortes-Hernandez J, Fossati-Jimack L, Bygrave AE, Walport MJ Vyse TJ, et al. Genetic dissection of spontaneous autoimmunity driven by 129 derived chromosome 1 Loci when expressed on C57BL/6 mice. J Immunol 2007; 178:2352-60.

[22] Richards HB, Satoh M, Jennette JC, Croker BP, Yoshida H, Reeves WH. Interferon-gamma is required for lupus nephritis in mice treated with the hydrocarbon oil pristane. Kidney Int 2001;60:2173-80.

[23] Jacob CO, van der Meide PH, McDevitt HO. In vivo treatment of (NZB X NZW) F1 lupus-like nephritis with monoclonal antibody to gamma interferon. J Exp Med 1987:166:798-803.

[24] Haas C, Ryffel B, Le HM. IFN-gamma is essential for the development of autoimmune glomerulonephritis in MRL/Ipr mice. J Immunol 1997;158:5484-91.

[25] Tucci M, Lombardi L, Richards HB, Dammacco F, Silvestris F. Overexpression of interleukin-12 and T helper 1 predominance in lupus nephritis. Clin Exp Immunol 2008;154:247-54.

[26] al-Janadi M, al-Balla S, al-Dalaan A, Raziuddin S. Cytokine profile in systemic lupus erythematosus, rheumatoid arthritis, and other rheumatic diseases. J Clin Immunol 1993;13:58-67.

[27] Bengtsson AA, Sturfelt G, Truedsson L, Blomberg J, Alm G, Vallin H, et al. Activation of type I interferon system in systemic lupus erythematosus correlates with disease activity but not with antiretroviral antibodies. Lupus 2000;9:664-71.

[28] Kikuchi S, Santiago-Raber ML, Amano H, Amano E, Fossati-Jimack L, Moll T, et al. Contribution of NZB autoimmunity 2 to Y-linked autoimmune acceleration-induced monocytosis in association with murine systemic lupus. J Immunol 2006;176:3240-7.

[29] Denny MF, Yalavarthi S, Zhao W, Thacker SG, Anderson M, Sandy AR, et al. A distinct subset of proinflammatory neutrophils isolated from patients with systemic lupus erythematosus induces vascular damage and synthesizes type I IFNs. J Immunol 2010;184:3284-97.

[30] Arbuckle MR, McClain MT, Rubertone MV, Scofield RH, Dennis GJ, James JA et al. Development of autoantibodies before the clinical onset of systemic lupus erythematosus. N Engl J Med 2003;349:1526-33.
[31] Bossie A, Vitetta ES. IFN-gamma enhances secretion of IgG2a from IgG2acommitted LPS-stimulated murine B cells: implications for the role of IFNgamma in class switching. Cell Immunol 1991;135:95-104.

[32] Finkelman FD, Katona IM, Mosmann TR, Coffman RL. IFN-gamma regulates the isotypes of Ig secreted during in vivo humoral immune responses. J Immunol 1988; 140:1022-7.

[33] Snapper CM, Peschel C, Paul WE. IFN-gamma stimulates IgG2a secretion by murine B cells stimulated with bacterial lipopolysaccharide. J Immunol 1988; $140: 2121-7$

[34] Baudino L, Azeredo da SS, Nakata M, Izui S. Molecular and cellular basis for pathogenicity of autoantibodies: lessons from murine monoclonal autoantibodies. Springer Semin Immunopathol 2006;28:175-84.

[35] Cisse B, Caton ML, Lehner M, Maeda T, Scheu S, Locksley R, et al. Transcription factor E2-2 is an essential and specific regulator of plasmacytoid dendritic cell development. Cell 2008;135:37-48.

[36] Driggers PH, Ennist DL, Gleason SL, Mak WH, Marks MS, Levi BZ, et al. An interferon gamma-regulated protein that binds the interferon-inducible enhancer element of major histocompatibility complex class I genes. Proc Natl Acad Sci U S A 1990;87:3743-7.

[37] Tamura T, Ozato K. ICSBP/IRF-8: its regulatory roles in the development of myeloid cells. J Interferon Cytokine Res 2002;22:145-52.

[38] Wang H, Morse III HC. IRF8 regulates myeloid and B lymphoid lineage diversification. Immunol Res 2009:43:109-17.

[39] Karlsson MC, Guinamard R, Bolland S, Sankala M, Steinman RM, Ravetch JV. Macrophages control the retention and trafficking of B lymphocytes in the splenic marginal zone. J Exp Med 2003;198:333-40.

[40] Nolte MA, Arens R, Kraus M, van Oers MH, Kraal G, van Lier RA, et al. B cells are crucial for both development and maintenance of the splenic marginal zone. J Immunol 2004;172:3620-7.

[41] McGaha TL, Chen Y, Ravishankar B, van RN, Karlsson MC Marginal zone macrophages suppress innate and adaptive immunity to apoptotic cells in the spleen. Blood 2011;117:5403-12.

[42] Kadowaki N, Ho S, Antonenko S, Malefyt RW, Kastelein RA, Bazan F, et al. Subsets of human dendritic cell precursors express different toll-like receptors and respond to different microbial antigens. J Exp Med 2001;194: 863-9.

[43] Liu YJ. IPC: professional type 1 interferon-producing cells and plasmacytoid dendritic cell precursors. Annu Rev Immunol 2005;23:275-306.

[44] Schiavoni G, Mattei F, Sestili P, Borghi P, Venditti M, Morse III HC, et al. ICSBP is essential for the development of mouse type I interferon-producing cells and for the generation and activation of CD8alpha $(+)$ dendritic cells. J Exp Med 2002;196:1415-25.

[45] Tsujimura H, Tamura T, Ozato K. Cutting edge: IFN consensus sequence binding protein/IFN regulatory factor 8 drives the development of type I IFN-producing plasmacytoid dendritic cells. J Immunol 2003; $170: 1131-5$

[46] Merino EJ, Wilkinson KA, Coughlan JL, Weeks KM. RNA structure analysis at single nucleotide resolution by selective 2'-hydroxyl acylation and primer extension (SHAPE). J Am Chem Soc 2005;127:4223-31.

[47] Stoecklin G, Stubbs T, Kedersha N, Wax S, Rigby WF, Blackwell TK, et al. MK2induced tristetraprolin:14-3-3 complexes prevent stress granule association and ARE-mRNA decay. EMBO J 2004;23:1313-24. 